\title{
Mesozoic dinosaurs from Brazil and their biogeographic implications
}

\author{
JONATHAS S. BITTENCOURT ${ }^{1}$ and MAX C. LANGER ${ }^{2}$ \\ ${ }^{1}$ Programa de Pós-Graduação em Biologia Comparada, Faculdade de Filosofia, Ciências e Letras de Ribeirão Preto \\ Universidade de São Paulo, Avenida Bandeirantes, 3900, Monte Alegre, 14040-901 Ribeirão Preto, SP, Brasil \\ ${ }^{2}$ Departamento de Biologia, Faculdade de Filosofia, Ciências e Letras de Ribeirão Preto \\ Universidade de São Paulo, Avenida Bandeirantes 3900, Monte Alegre, 14040-901 Ribeirão Preto, SP, Brasil \\ Manuscript received on February 3, 2010; accepted for publication on September 14, 2010
}

\begin{abstract}
The record of dinosaur body-fossils in the Brazilian Mesozoic is restricted to the Triassic of Rio Grande do Sul and Cretaceous of various parts of the country. This includes 21 named species, two of which were regarded as nomina dubia, and 19 consensually assigned to Dinosauria. Additional eight supraspecific taxa have been identified based on fragmentary specimens and numerous dinosaur footprints known in Brazil. In fact, most Brazilian specimens related to dinosaurs are composed of isolated teeth and vertebrae. Despite the increase of fieldwork during the last decade, there are still no dinosaur body-fossils of Jurassic age and the evidence of ornithischians in Brazil is very limited. Dinosaur faunas from this country are generally correlated with those from other parts of Gondwana throughout the Mesozoic. During the Late Triassic, there is a close correspondence to Argentina and other south-Pangaea areas. Mid-Cretaceous faunas of northeastern Brazil resemble those of coeval deposits of North Africa and Argentina. Southern hemisphere spinosaurids are restricted to Africa and Brazil, whereas abelisaurids are still unknown in the Early Cretaceous of the latter. Late Cretaceous dinosaur assemblages of south-central Brazil are endemic only to genus or, more conspicuously, to species level, sharing closely related taxa with Argentina, Madagascar, Indo-Pakistan and, to a lesser degree, continental Africa.
\end{abstract}

Key words: Brazil, Dinosauria, Triassic, Jurassic, Cretaceous, paleobiogeography.

\section{INTRODUCTION}

The sesquicentennial history of dinosaur research in Brazil (e.g., Allport 1860, Marsh 1869, Mawson and Woodward 1907, Huene 1942, Price 1960, 1961, Colbert 1970, Arid and Vizotto 1971, Bertini and Campos 1987, Frey and Martill 1995, Kellner and Campos 1996) is experiencing, since the last decade, its more prolific period. Taxa from a variety of dinosaur clades have been recorded in the Triassic strata of the Santa Maria and Caturrita formations (Langer et al. 2007a), the mid-Cretaceous of the Araripe and São Luís-Grajaú basins (Frey and Martill 1995, Kellner 1996a, b, 1999, Medeiros et al. 2007), and the Late Cretaceous of Bauru

Proceedings of the Third Gondwanan Dinosaur Symposium Correspondence to: Jonathas Bittencourt

E-mail: jonathas@pg.ffclrp.usp.br and Parecis groups (Franco-Rosas et al. 2004, Kellner et al. 2004). Although still limited for some geologic periods and taxa (Kellner and Campos 2000), Brazilian dinosaur records have yielded significant data for studies of the phylogeny and evolution of the group in the Mesozoic. Among several aspects of dinosaur research that are drawing attention in the last years, biogeography is particularly noticeable (Forster 1999, Sereno 1999a, Upchurch et al. 2002, Butler et al. 2006, Smith et al. 2008, Nesbitt et al. 2009). Indeed, biogeography is growing as a science (Lomolino et al. 2006, Morrone and Guerrero 2008), and much of its conceptual framework is well set. Nonetheless, as emphasized by several authors (e.g., Lieberman 2002, 2003), accurate interpretations of the fossil record are necessary starting-points for constructing reliable hypotheses of 
endemic range, upon which all paleobiogeographic hypotheses are erected. In this paper, we provide a reevaluation of the Brazilian dinosaur record from Triassic to Cretaceous ages based primarily on body-fossils, and discuss their relevance in the light of recent hypotheses dealing with dinosaur biogeography in the Mesozoic (Upchurch et al. 2002, Sereno et al. 2004, Krause et al. 2006, Nesbitt et al. 2009).

\section{DINOSAUR RECORD IN THE BRAZILIAN MESOZOIC}

Gondwana II Supersequence (PARANÁ BASIN)

Triassic dinosaurs in Brazil were exclusively collected from rocks of the Santa Maria and the overlying Caturrita formations, in central Rio Grande do Sul (Fig. 1, Table I, II, Langer et al. 2007a). These units belong to the Rosário do Sul Group (Andreis et al. 1980), which corresponds to the Gondwana Supersequence II of the Paraná Basin (Milani 2004). Recent studies explain the origin of this Supersequence as the infilling of tectonically restricted half-graben depocenters (Milani 2001, 2004, Zerfass et al. 2003). The Santa Maria Formation is composed predominantly of red mudstones (Andreis et al. 1980, Scherer et al. 2000, Silva et al. 2003) and encompasses two distinct faunal associations of Ladinian and Carnian age (Barberena 1977, Langer et al. 2007a), as also suggested by stratigraphic studies (Zerfass et al. 2003). The Ladinian sequence represents a more humid phase within a generally seasonal and semi-arid climate. Fossil tetrapods were preserved either in lacustrine environments or in flood plains of an anastomosed fluvial system (Scherer et al. 2000, Zerfass et al. 2003). The Carnian sequence was formed in a similar environment, but the presence of aeolian deposits suggests an increased aridity (Zerfass et al. 2003). The coarser-grained, red sandstones of the Caturrita Formation represent the establishment of a perennial braided fluvial system, hinting at the return of more humid conditions (Holz and Scherer 2000, Zerfass et al. 2003). The age of this unit has been generally accepted as Norian (Rubert and Schultz 2004, Bonaparte et al. 2007, Langer et al. 2007a).

The only possible dinosaur recovered from the Ladinian sequence of the Santa Maria Formation is Spondylosoma absconditum Huene, 1942 (Table II). Proposed affinities for this taxon varied from Saurischia
(Huene 1942, Langer 2004) to Pseudosuchia (Galton 2000), or even Silesauridae (Dzik 2003). However, the specimens referred to this taxon, which include isolated vertebrae, teeth, elements of the pectoral member and pelvic girdle (Galton 2000), are too incomplete to allow their unequivocal identification as a dinosaur (Langer et al. 2010). No osteological remains from other parts of Pangaea suggest the presence of dinosaurs in the Ladinian, but possible footprints from Europe and Argentina (Haubold and Klein 2002, Marsicano and Barredo 2004, Diedrich 2009) may represent earliest dinosaurs in the fossil record. Although the attribution of several of these Triassic footprints has been disputed (King and Benton 1996), the issue is still unresolved (Melchor and de Valais 2006, Marsicano et al. 2007, Silva et al. 2008).

The Carnian witnessed the beginning of the dinosaur radiation, although taxa attributed to this clade are still rare (Langer et al. 2010, Nesbitt et al. 2009). This radiation has been studied in the light of the climatic changes registered in the end of the Triassic (Tucker and Benton 1982, Golonka and Ford 2000). In the Late Triassic strata of Rio Grande do Sul, these events are represented by an aridity increase during the Carnian (Zerfass et al. 2003), leading to the establishment of a mesoxerophytic flora dominated by the gymnosperm Dicroidium and concomitant faunal changing (Azevedo et al. 1990).

Herbivorous dicynodonts were the dominant primary consumers in pre-Carnian stages of the Santa Maria Formation paleoenvironment. In the Carnian-Norian, this dominance decreased with the diversification of rhynchosaurs, with a maxillomandibular apparatus specialized in crushing hard plant material (Benton 1983b), and the arising of small herbivorous/omnivorous dinosauriforms as Saturnalia tupiniquim Langer et al. 1999, and Sacisaurus agudoensis Ferigolo and Langer 2007. In addition, recent fieldwork in the Santa Maria Formation suggests the presence of larger-bodied sauropodomorphs anatomically similar to Saturnalia (Da Rosa et al. 2006). Secondary consumers, predominantly composed by rauisuchian taxa in the Ladinian, became more diversified in the Carnian with the arising of small-bodied saurischians represented by the herrerasaurid Staurikosaurus pricei Colbert, 1970. Herrerasaurids are well known in South American Carnian strata (Sereno and 


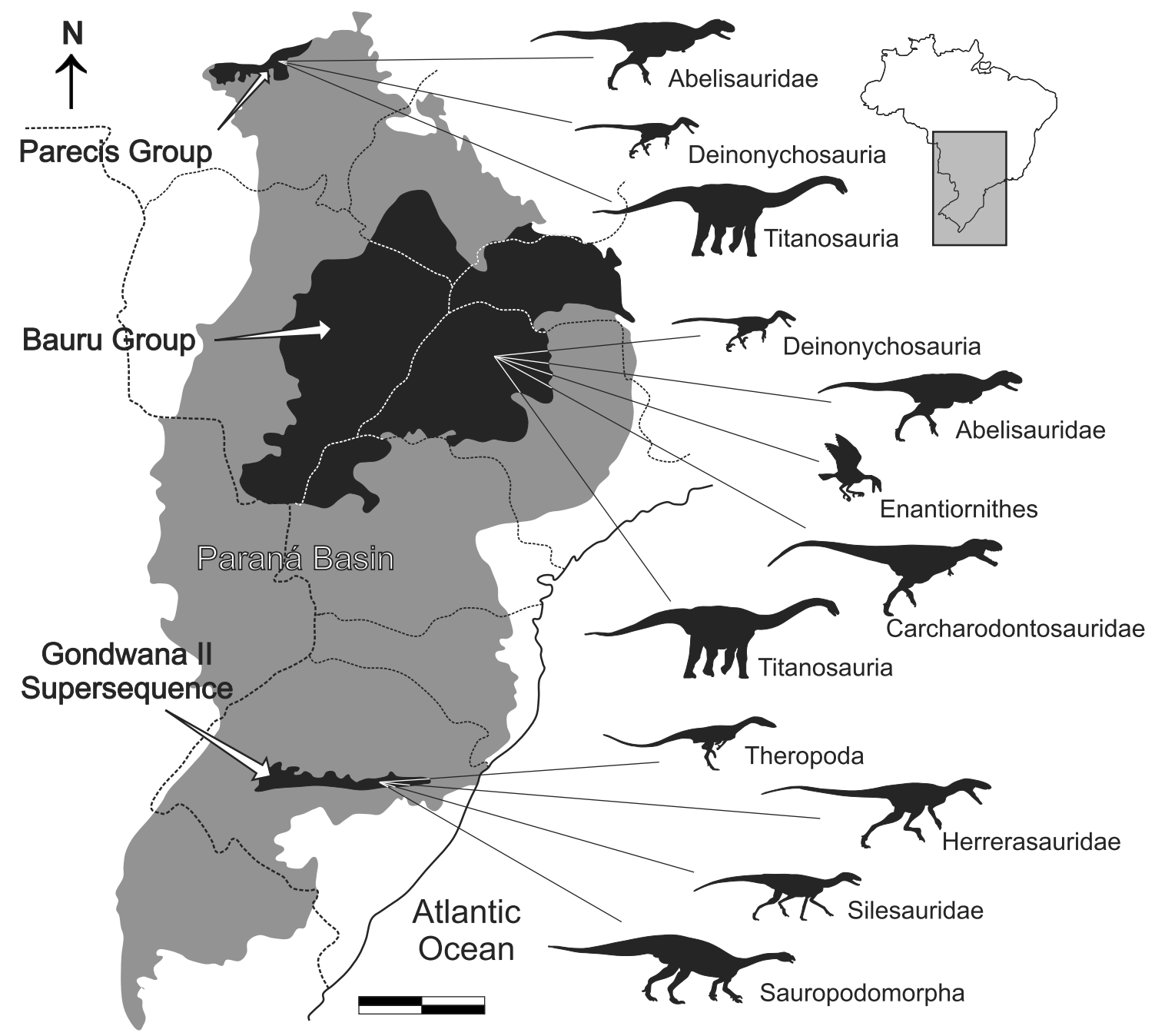

Fig. 1 - Map of south-central Brazil depicting the Paraná Basin (grey), and Gondwana II Supersequence, Bauru and Parecis groups (black). The dinosaur record follows Tables I-II. Modified from Silva et al. (2003) and Milani (2004). Scale $=200 \mathrm{~km}$.

Novas 1992, Novas 1997, Langer 2004, Bittencourt and Kellner 2009, Alcober and Martinez 2010, Langer et al. 2010). Norian records from the Chinle Formation (Long and Murry 1995, Nesbitt et al. 2007) and Dockum Group (Nesbitt and Chatterjee 2008) have been recurrently mentioned (Irmis et al. 2007a, Nesbitt et al. 2009, 2010), but these are based on less complete material. Herrerasaurids have been preliminary reported in India (Novas et al. 2009a), but additional data is needed to fully evaluate these occurrences. Basal members of the sauropodomorph lineage are represented by Saturnalia and other Gondwanan records, such as Panphagia protos Matinez and Alcober 2009 and Chromogisaurus novasi Ezcurra 2010, both from the Ischigualasto Formation,
Argentina, and a possible occurrence in southern Africa (Raath 1996, Langer et al. 1999). Some authors have proposed a close relationship between these widespread taxa/specimens (Ezcurra and Novas 2009, Ezcurra 2010). If this hypothesis is confirmed, the saturnalian lineage would represent the first sauropodomorph-related radiation in the southern hemisphere.

From a global perspective, dinosaur diversification becomes more evident in the Norian, when sauropodomorphs and theropods are variably registered in Argentina, North America, Europe, and South Africa (Benton 1983a, Crompton and Attridge 1986, Galton 1990, Colbert 1989). The dinosaur record of the Caturrita Formation follows that pattern: Guaibasaurus candelarien- 
sis probably represents a theropod (Fig. 2) (Bonaparte et al. 1999, Langer et al. 2007b, Bittencourt 2008), although this classification has been disputed in favor of a sauropodomorph affinity (Bonaparte et al. 2007, Ezcurra 2010), while the plateosaurid Unaysaurus tolentinoi, described by Leal et al. (2004), represents a South American branch of the worldwide prosauropod diversification (Fig. 2) (Buffetaut et al. 1995, Galton and Upchurch 2004a, Yates 2007a). Additional saurischian specimens recovered from the Caturrita Formation require further inquiry to allow a robust classification within any dinosaurian clade (Kischlat and Barberena 1999, Lyrio et al. 2004).

The recent discovery of two new dinosaur-related forms from the Santa Maria beds provides significant biogeographic data on the origin and early evolution of dinosaurs. Cabreira et al. (2007) announced an alleged primitive neotheropod with coelophysoid affinities from the Carnian of Santa Maria Formation based on cranial and postcranial remains. However, this specimen bears similarities with some basal sauropodomorphs (e.g., Langer et al. 1999, Martinez and Alcober 2009). The dinosauriform Sacisaurus agudoensis from the Caturrita Formation (Ferigolo and Langer 2007) is allied with Silesaurus opolensis from the Carnian of Poland (Dzik 2003), in the Silesauridae. This clade encompasses other species from North America, Africa, and South America (Irmis et al. 2007a, Bittencourt and Langer 2009, Nesbitt et al. 2009, 2010, Langer et al. 2010), ranging from Anisian to Norian times. In this context, S. agudoensis is a late representative of the silesaurids. The phylogenetic position of this group as basal dinosauriforms is better supported by cladistic analyses (Langer 2004, Ezcurra 2006, Langer and Benton 2006, Yates 2007a, b, Irmis et al. 2007a, Nesbitt et al. 2009, 2010), although an ornithischian affinity has been suggested by many authors (Dzik and Sulej 2007, Ferigolo and Langer 2007, Langer et al. 2007a, Niedzwiedzki et al. 2009). The biogeographic and biochronological implication of this conundrum is evident. If silesaurids are treated as ornithischians, the occurrence of silesaurids in Anisian strata of the African Manda Formation (Nesbitt et al. 2010) results in a ghost lineage for Saurischia, because the oldest (Carnian) unambiguous record of this clade is at least 10 million years younger (Rogers et al. 1993). Alterna- tively, if silesaurids are not ornithischians, the low diversity of the latter group in comparison with saurischians in Late Triassic vertebrate assemblages remains to be satisfactorily explained. This is especially intriguing for the Carnian-Norian of south Brazil, as ornithischian taxa are known from correlated deposits of both Argentina and South Africa (Casamiquela 1967, Báez and Marsicano 2001, Irmis et al. 2007b, Butler et al. 2007).

\section{ARARIPE BASIN}

Dinosaurs from the Araripe Basin (Fig. 3, Table I, II) are restricted to the Santana Formation, which was deposited in the context of post-rift tectonic events that led to the fragmentation of Gondwana and opening of the South Atlantic Ocean (Ponte and Appi 1990, Ponte 1996, Ponte and Ponte Filho 1996). This includes the Rio da Batateira Formation, which initiates a regressivetransgressive sedimentary cycle with the deposition of fluviolacustrine sediments into the depressions formed during rifting (Ponte and Ponte Filho 1996). The overlying Santana Formation is associated with the subsequent development of an extensive lacustrine system and an eventually massive marine incursion (Maisey 1991, Arai and Coimbra 1990). This sequence ends with the regressive phase of the cycle, represented by the fluvial sandstones of the Exu Formation (Beurlen 1971, Assine 1992). The main fossil bearing localities of the Santana Formation, in the northeastern region of Brazil, are widespread along the borders of the Araripe Plateau (Kellner and Campos 1999, 2000, Kellner 2002a, Kellner et al. 2002, Viana and Neumann 2002, Martill 2007a). Several authors divide the Santana Formation into Crato, Ipubi, and Romualdo members (Beurlen 1971, Ponte and Ponte Filho 1996, Kellner and Campos 1999, 2000, Fara et al. 2005). This proposal will be followed here, although the treatment of these subunits as individual formations has also gained support in the literature (Assine 1992, Martill 1993, Martill and Wilby 1993, Neumann and Cabrera 1999, Maisey 2000, Martill 2007a, Martill and Heimhofer 2007).

The geology of the Crato Member has been recently reviewed (see Martill et al. 2007a) and only a brief summary is presented here. This unit is composed of laminated limestone deposited in a lacustrine context during Aptian-Albian times (Pons et al. 1990, Pon- 


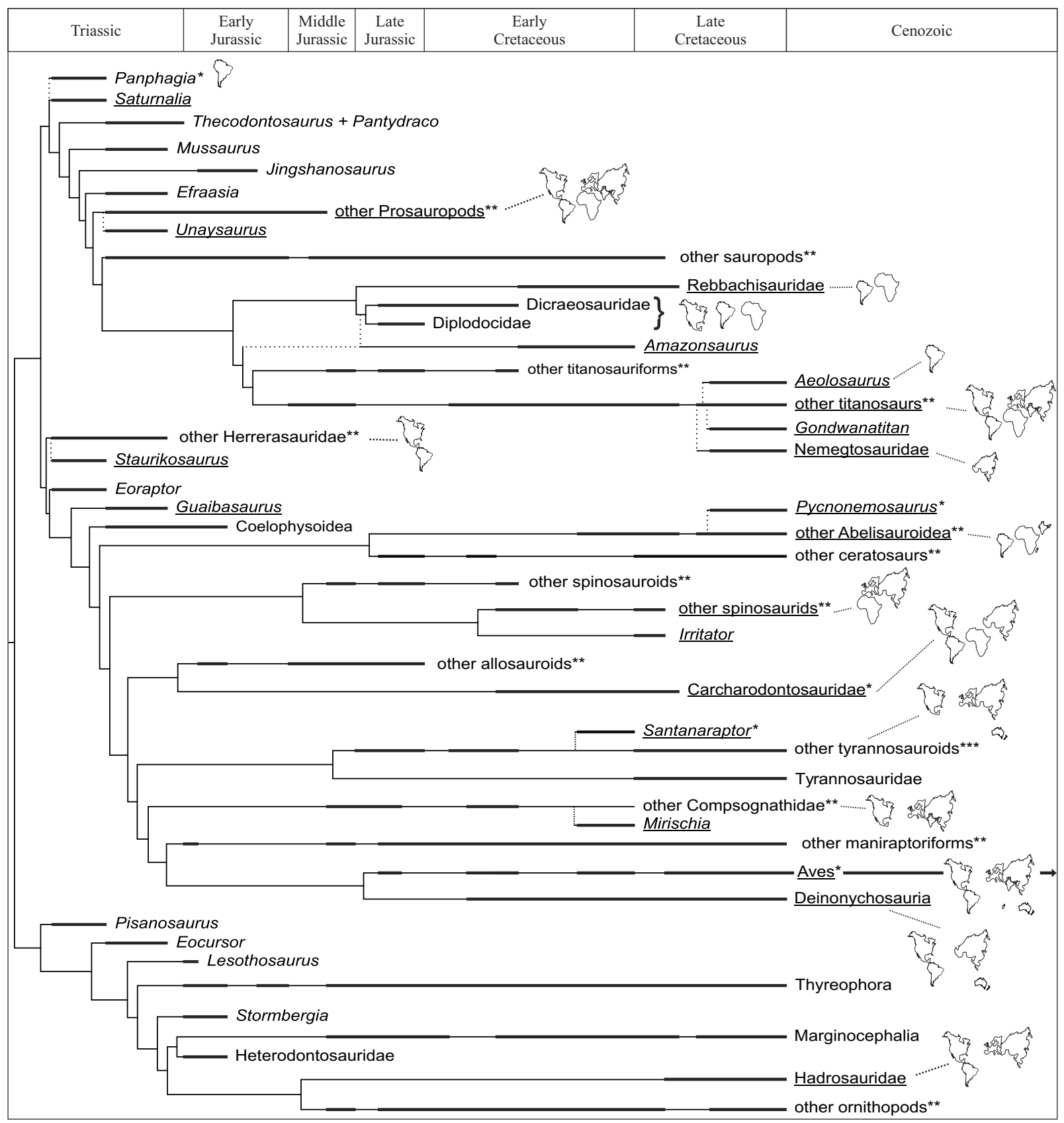

Fig. 2 - Cladogram depicting the phylogenetic relationships within dinosaurs, with emphasis on the Mesozoic record from Brazil. Modified from Lloyd et al. (2008). Thicker lines over branches represent temporal range of the clade. Underlined names refer to taxa recorded in Brazil, and maps denote the records in areas other than Brazil. $(*)$ Taxa not present or with distinct composition in comparison with the original tree. $(* *)$ Paraphyletic groups. Some taxa from the original cladogram were omitted. Assemblage of supraespecific taxa followed the clade definitions from TaxonSearch (Sereno et al. 2005). Maps redrawn from Turner (2004).

te and Ponte Filho 1996, Maisey 2000, Neumann et al. 2002, Silva et al. 2002, Viana and Neumann 2002). The depositional settings have variously been interpreted as either fresh, brackish, or hypersaline waters (Martill 2007a, Martill and Bechly 2007, Martill et al. 2007b), but their fauna better corresponds to that of a non-ma- 


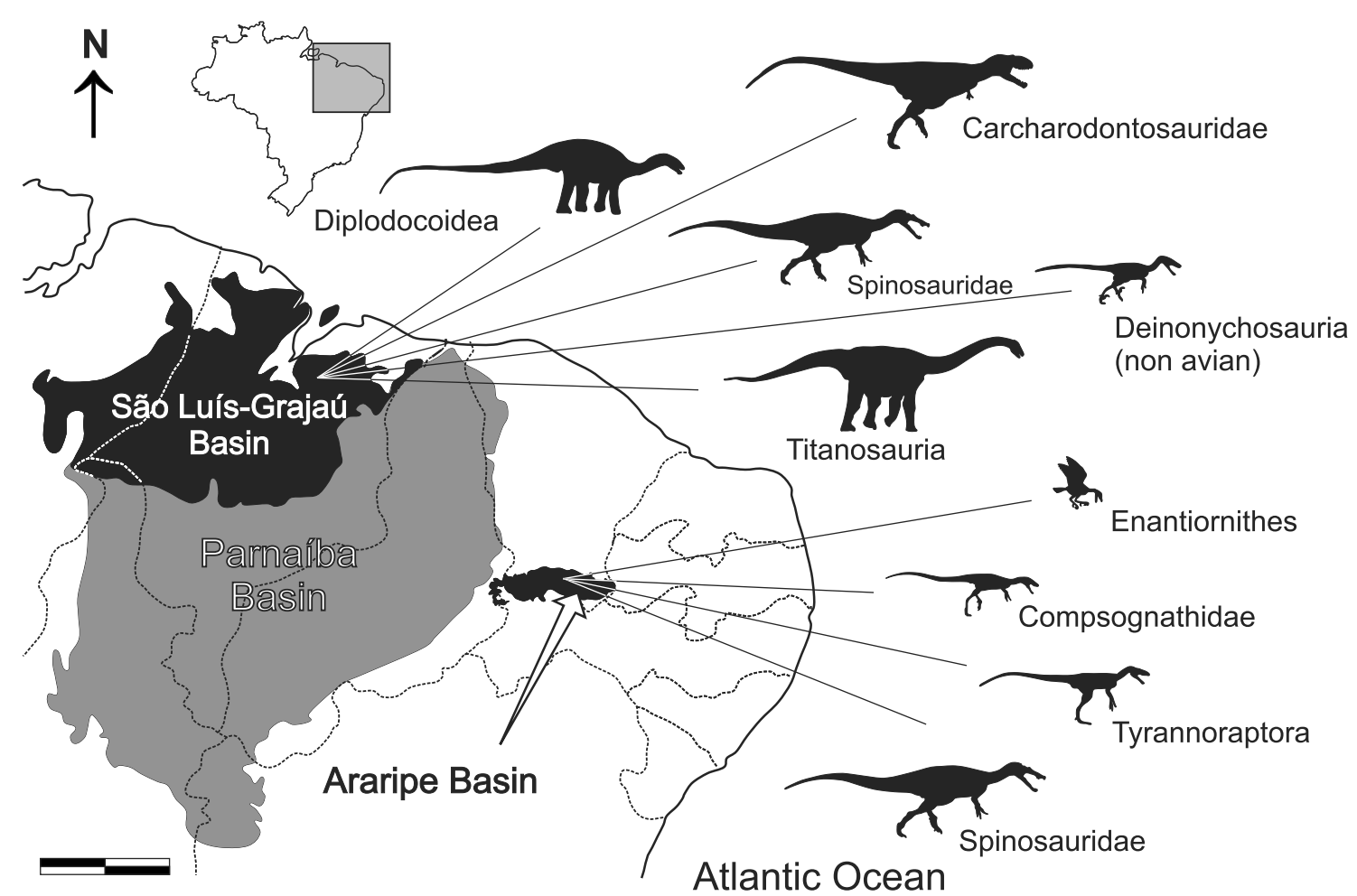

Fig. 3 - Map of northeastern Brazil depicting the Parnaíba Basin (grey), and São Luís-Grajaú and Araripe basins (black). The dinosaur record follows Tables I-II. Modified from Martill (1993), Rossetti (2001) and Santos and Carvalho (2004). Scale = $200 \mathrm{~km}$.

rine environment (Maisey 1990, 1991, 2000). Due to the exquisite fossil preservation, the Crato Member is the first of two Lagerstätten of the Santana Formation (Kellner and Campos 1999). The Ipubi Member represents a transitional evaporitic phase (Beurlen 1971, Ponte and Ponte Filho 1996, Martill and Wilby 1993), and its fossil content, which does not include dinosaurs, is insignificant if compared to the other stratigraphic units of the Santana Formation (Kellner 1999). The Romualdo Member is mainly composed of shale and marls whose fossils are three-dimensionally preserved in calcareous nodules (Kellner and Campos 1999, 2000). Due to the high diversity, abundance and excellent preservation of the specimens, this member represents the second Lagerstätte of the Santana Formation (Kellner and Campos 1999, Fara et al. 2005). The sediments of this unit are Albian in age (Pons et al. 1990, but see Martill 2007b) and were deposited in a shallow brackish environment, which was formed during an episodic marine incursion (Ponte and Ponte Filho, 1996). For some authors (Arai and Coimbra 1990, Arai 1999), the Santana Formation is part of a massive transgressive event, which formed an epicontinetal sea over a significant portion of north-northeastern Brazil (but see Martill 2007a). Whichever scenario is better supported by available data, the dinosaurs are land-dwelling, and can be regarded as allochtonous components of the Romualdo Member thanatocenoses (Naish et al. 2004).

All dinosaurs from the Santana Formation are theropods (Table I, II), and at least four different clades have been identified. The only mention of ornithischians (Leonardi and Borgomanero 1981) was based on a bone fragment interpreted as part of an ischium, later reidentified as a rib and tentatively assigned to a spinosaurid due to its size (Machado and Kellner 2007). Several types of feathers from the Crato Member (Martins Neto and Kellner 1988, Kellner 2002b, Kellner et al. 1994, Martill and Figueira 1994, Martill and Frey 1995) initially hint at the presence of avian taxa in the Aptian-Albian of northeastern Brazil. However, this hypothesis has been challenged by the occurrence of asymmetrical feathers in non-avian eumaniraptorans (Witmer 2002). On the other hand, based on two poorly preserved specimens, Naish et al. (2007) reported possible birds from the Crato 
Member. One of the specimens is quite incomplete and housed in Frankfurt; the other is more complete and held in a private collection in Japan. The authors did not provide further data on the provenance of the specimens, as occur with most materials from the Santana Formation often collected without any stratigraphical control (Fara et al. 2005). Among the relevant features described by Naish et al. (2007, plates 25-26), the Frankfurt specimen bears evidence of asymmetrical feathers, while the Japan individual shows a reversed hallux. The occurrence of Aves in the Crato Formation is expected both chronostratigraphically and biogeographically, as this clade is known since the Late Jurassic and widespread in the Early Cretaceous (Fig. 2, 4b) (Padian 2004).

The most common theropods from the Santana Formation are the spinosaurids, with two described species and additional postcranial remains (Martill et al. 1996, Kellner and Campos 1996, Kellner 1996b, Sues et al. 2002, Bittencourt and Kellner 2004, Machado and Kellner 2005). This clade (Fig. 2) has been recorded in the Barremian of Europe (Charig and Milner 1997, Buffetaut 2007) and Early Cretaceous of Thailand and China (Buffetaut and Ingavat 1986, Buffetaut et al. 2008), but reached its greatest diversity in the Aptian-Cenomanian of northern Africa (Fig. 4b, Stromer 1915, Taquet and Russell 1998, Sereno et al. 1998, Buffetaut and Ouaja 2002, Dal Sasso et al. 2005, Smith et al. 2006), when faunistic similarities with northeastern Brazil are evident. Typical Laurasian theropod clades have been tentatively reported in the Romualdo Member of the Santana Formation. Frey and Martill (1995) referred an incomplete sacrum to Oviraptorosauria, a group that has also been registered in other parts of the Gondwana, as Australia (Currie et al. 1996) and Argentina (Frankfurt and Chiappe 1999). However, more recent studies contested these evidences (Makovicky and Sues 1998, Kellner 1996b, Agnolín and Martinelli 2007), and further work is needed to confirm the Gondwanan occurrence of this clade. The small-bodied Santanaraptor placidus, based on an incomplete postcranial skeleton not yet described in detail, was initially related to Maniraptoriformes (Kellner 1999) and later to Tyrannoraptora (Kellner 2001). Although both clades have controversial definitions in the literature (Sereno 1999b, Holtz 2004, Holtz et al. 2004, Senter 2007), their representatives are known in virtually all continents at the end of the Early Cretaceous (Rauhut 2003). Holtz (2004) referred S. placidus to Tyrannosauroidea (Fig. 2), which is congruent with at least another Gondwanan occurrence of the group (Benson et al. 2010). The clade Compsognathidae was identified in the Santana Formation based on the skeletal remains attributed to Mirischia asymmetrica (Martill et al. 2000, Naish et al. 2004). This is both the only Gondwanan and the youngest record of the group, otherwise known only from the Late Jurassic and Early Cretaceous of China and Europe (Zhou et al. 2003, Holtz et al. 2004, Hwang et al. 2004, Naish et al. 2004).

\section{SÃo LUÚS-GRAJAÚ BASIN}

The São Luís-Grajaú Basin was formed by partial subsidence of the former Parnaiba Basin (Fig. 3), following the uplift of the Ximbioa Arc during the opening of the South Atlantic Ocean, in an area corresponding to the north of the Maranhão State (Góes and Rossetti 2001, Santos and Carvalho 2004). The dinosaurs from this region (Carvalho et al. 2003, Medeiros et al. 2007) were all recovered from rocks of the Itapecuru Group, which overly the lacustrine deposits of the Codó Formation and the aeolian sandstones of the Grajaú Formation, both of Aptian age (Rossetti et al. 2001a). According to Rossetti (2001), but see also Rossetti and Truckenbrodt (1997) and Santos and Carvalho (2004), the Itapecuru Group is divided in three stratigraphic units: a) the Albian age "Undifferentiated Unit", represented by several localities with complex and diverse lithology associated with marine, lacustrine, and floodplain environments; $b$ ) the Alcântara Formation, composed of stratified sandstones, mudstones, and limestones deposited during the early Cenomanian in an estuarine environment; c) the Cujupe Formation whose age ranges from the Late Cretaceous to Paleocene, and devoid of dinosaur records. Rossetti et al. (2001b) suggested a dry, warm climate during the deposition of the "Undifferentiated Unit", whereas the Alcântara Formation is associated with an increasingly humid, but still seasonal semi-arid climate. The so-called "Itapecuru Formation", which crops out in the Itapecuru-Mirim region (Ferreira et al. 1992, Carvalho et al. 2003), is an informal unit that roughly corresponds to the "Undifferentiated Unit" (Rossetti et al. 
(a)
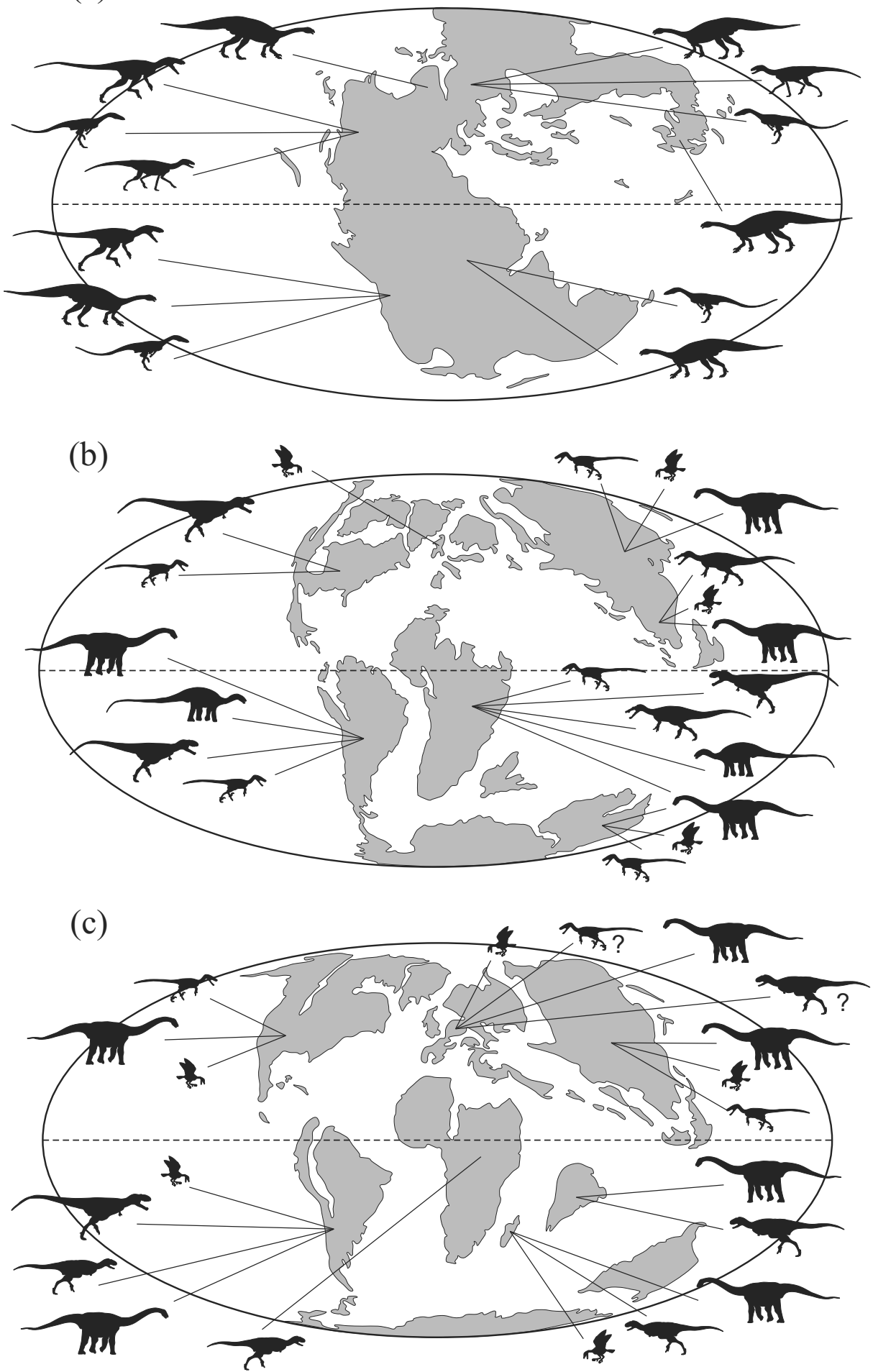

Fig. 4 - Paleogeographic reconstructions corresponding to Late Triassic (a), "middle" (b) and Late Cretaceous (c). Modified from Blakey (2006). The outlines (as in Figs. 1,4) indicate other occurences of dinosaur/dinosauromorph clades recorded in Brazil during Carnian-Norian, Aptian-Cenomanian, and Campanian-Maastrichtian respectively. 
2001a, Santos and Carvalho 2004). The most important fossil localities with dinosaur remains of the São Luís-Grajaú Basin are: Coroatá and Mata ("Undifferentiated Unit”/“Itapecuru Formation”: Carvalho et al. 2003, Ribeiro et al. 2003, Castro et al. 2007) and Ilha do Cajual and Praia da Baronesa (Alcântara Formation: Elias et al. 2007, Medeiros et al. 2007).

The Itapecuru Group dinosaur fauna (Fig. 3, Table I, II) based on skeletal remains includes specimens attributed to Sauropoda and Theropoda (Carvalho et al. 2003, Medeiros et al. 2007), and a possible ornithischian record (Avilla et al. 2003). Carvalho and Pedrão (2000) have recorded theropod and ornithischians footprints. The fossil preservation is, however, not exceptional, hampering their identification. Among theropods, several genera from North Africa as Carcharodontosaurus, Sigilmassasaurus (Sereno et al. 1996, Novas et al. 2005a, 2006, Brusatte and Sereno 2007), and Spinosaurus have been reported based on isolated vertebrae and teeth (Vilas Bôas et al. 1999, Medeiros 2006, Medeiros and Schultz 2001, 2002, Medeiros et al. 2007, Ribeiro et al. 2003). Yet, the diagnoses of these taxa include anatomical details not available in the Itapecuru Group material, and they are here treated only as indeterminate Carcharodontosauridae and Spinosauridae (Table I, II). Additionally, the record (Medeiros and Schultz 2002, p. 156) of "Baharijasaurus" [sic] (= Bahariasaurus Stromer 1934), a possible carcharodontosaurid from North Africa (Rauhut 1995, Holtz et al. 2004), is also uncertain and here referred to as an indeterminate theropod. Carcharodontosauridae and Spinosauridae specimens are known from both the "Undifferentiated Unit" and the Alcântara Formation, the latter also yielding a new spinosaurid (see Kellner et al. 2011), increasing to 19 the number of dinosauriform species from Brazil consensually assigned to Dinosauria. These records are congruent with the already mentioned abundance of spinosaurids in the Cenomanian of North Africa (Fig. 2, 4b) (Russell 1996, Sereno et al. 1998, Dal Sasso et al. 2005, Smith et al. 2006). Carcharodontosaurids are also common in the Aptian to Cenomanian of Africa and South America (Holtz et al. 2004, Sereno et al. 2004, Novas et al. 2005a, Brusatte and Sereno 2007, 2008, Casal et al. 2009), as well as in older Laurasian deposits (Holtz et al. 2004).
Further isolated teeth from the Itapecuru Group were referred to Velociraptorinae (Elias et al. 2007), a maniraptoran group of disputed taxonomic validity within Dromaeosauridae (Makovicky et al. 2005), recorded in the Early Cretaceous of North America and Late Cretaceous of Eurasia (Norell and Makovicky 2004). In this work, we consider all Brazilian records of Velociraptorinae (see below: Bauru Supersequence) as indeterminate Deinonychosauria (Table I, II), pending new findings that would allow a more accurate identification of these specimens. In Gondwana, dromaeosaurid deinonychosaurs are known based on several species from the Cenomanian-Maastrichtian of Argentina (Novas and Puerta 1997, Novas and Pol 2005, Calvo et al. 2004, Makovicky et al. 2005, Novas et al. 2009b), with possible records in the Cenomanian of central Africa (Rauhut and Werner 1995) and Albian of Australia (Fig. 4b) (Currie et al. 1996).

The sauropod fauna of the Itapecuru Group (Tables I, II) includes Diplodocoidea and Titanosauria, as well as specimens of uncertain affinities (e.g., Astrodon", Medeiros and Schultz 2001, Medeiros et al. 2007). Diplodocoids are represented by Amazonsaurus maranhensis (Carvalho et al. 2003) and indeterminate remains (Castro et al. 2007) recovered from the "Undifferentiated Unit" ("Itapecuru Formation"). Some authors regarded $A$. maranhensis as a basal macronarian (Rauhut et al. 2005, Lloyd et al. 2008), but most phylogenetic studies refer this species to as diplodocoid (Salgado et al. 2004). This taxon is both geographically and chronologically widespread, with coeval records in Argentina, Africa and North America (Figs. 2, 4b) (Upchurch et al. 2004, Wilson 2005). Several isolated specimens have been regarded as Rebbachisauridae (Medeiros and Schultz 2001, 2004, Medeiros et al. 2007), a group with an abundant record in Aptian-Coniacian deposits of Argentina and North Africa (Upchurch et al. 2004, Gallina and Apesteguía, 2005), but also from older strata of Europe (Sereno and Wilson 2005, Sereno et al. 2007, Mannion 2009) and possibly South Africa (Figs. 2, 4b) (Canudo and Salgado 2003). According to Medeiros and Schultz (2004), some specimens from the Alcântara Formation have affinities with "Rebbachisaurus" tamesnensis (Lapparent 1960), a North African taxon with uncertain status (Calvo and Salgado 1995, Sereno 
et al. 1999, Upchurch et al. 2004), and with the better known Rayososaurus tessonei. The latter has been referred to Limaysaurus by Salgado et al. (2004) and recorded in the Aptian-Cenomanian of Argentina (Calvo and Salgado 1995). Among Titanosauria, a group better discussed in the next section, indeterminate fragments were recovered from both the "Undifferentiated Unit" (Castro et al. 2007) and the Alcântara Formation, i.e., ?Aegyptosaurus, ?Malawisaurus, and "Titanosauridae" (Medeiros and Schultz 2001, Medeiros et al. 2007). Medeiros and Schultz (2002) also mentioned the presence of andesaurid remains in the Alcântara Formation. This poorly known and probably paraphyletic group has been described from the Cretaceous of Argentina (Bonaparte and Coria 1993, Salgado et al. 1997) with possible records in the Albian of North Africa (Russell 1996).

\section{BAURU AND PARECIS GROUPS}

The Cretaceous of the Bauru Group (sensu Soares et al. 1980) has so far provided the most significant record of Brazilian dinosaurs (Kellner and Campos 2000). Its strata are also referred to as Bauru Supersequence (Fig. 1, sensu Milani 2001) and were formed in an extensive subsidence area created by the lithostatic load of the Early Cretaceous basalts of the Serra Geral Formation, upon which the Bauru beds are discordantly deposited (Fulfaro and Perinotto 1996, Fernandes and Coimbra 2000, Milani 2004). Concentrated in the central-northern portion of the Paraná Basin, depocenter of the preceeding massive basalt flood (Zalán et al. 1990), the main body of the Bauru Supersequence ranges from São Paulo and western Minas Gerais to northwestern Paraná, eastern Mato Grosso do Sul and southern Goiás (Fig. 1). Some authors consider that the Bauru beds were deposited in a differentiated tectonic context (i.e., the Bauru Basin, see Fulfaro and Perinotto 1996, Fernandes and Coimbra 2000, Fernandes 2004), but we follow the more traditional view, which includes the Bauru strata within the Paraná Basin (Baptista et al. 1984, Soares et al. 1980, Mezzalira 1981, Milani 2004).

The Bauru dinosaurs (Table I, II) are commonly found in localities of western São Paulo and Minas Gerais, where the Adamantina and Marília formations are widely known for their rich fossiliferous content (Bertini et al. 2003, Candeiro et al. 2006a, 2008). These stratigraphic units have been split in several smaller units (Fernandes and Coimbra 2000, Fernandes 2004), but the traditional nomenclature of Soares et al. (1980) is still largely used in paleontological studies. This occurs mainly because of the problem of referring earlier fossil findings to the new units of more elaborated stratigraphic frameworks. In an attempt to fully exploit the biogeographic data, we will again follow this traditional interpretation. The age of the Adamantina Formation as Campanian-Maastrichtian (Gobbo-Rodrigues et al. 1999, Santucci and Bertini 2001) has been challenged by Dias-Brito et al. (2001) who proposed an older (i.e., Turonian-Santonian) age for this unit. However, we agree with Gobbo-Rodrigues et al. (2003) that the concomitant occurrence of microfossils typical of Aptian-Cenomanian and Campanian-Maastrichtian intervals (Dias-Brito et al. 2001, p. 278) are not conclusive evidence for ascribing an intermediate age for the Adamantina Formation. However, it should be noted that this stratigraphical unit originated from different depositional cycles, as suggested by its division into superposed smaller units (Fernandes and Coimbra 2000). In addition, some dinosaur records that indicate a younger age for the Adamantina Formation (R.M. Santucci unpublished data) apparently comes from upper cycles (Localities L2 and L26 of Dias-Brito et al. 2001), suggesting that the Adamantina Formation congregates rocks of significantly different ages, with still poorly sampled individual biotas. The geological setting of this stratigraphic unit encompasses aeolian, lacustrine, and fluvial, i.e. braided meandering rivers, deposits (Fernandes 2004). Current data support a warm, seasonal, and arid to semi-arid climate with more humid periods (Goldberg and Garcia 2000, Dias-Brito et al. 2001). According to Goldberg and Garcia (2000), the arid conditions increased towards the top of the Bauru Group, represented by the Marília Formation. This unit is divided into the Serra da Galga, Ponte Alta, and Echaporã members, composed of alluvial fans associated with braided canals and subordinated levels of aeolian sediments and calcrete (Fernandes and Coimbra 2000). The age of the Marília Formation is generally accepted as Maastrichtian (Gobbo-Rodrigues et al. 1999, Dias-Brito et al. 2001, Campos et al. 2005).

Cretaceous deposits of the northwestern margin of 
the Paraná Basin crop out in the state of Mato Grosso (Fig. 1). Their strata have been referred to the Cambambe Formation (sensu Weska et al. 1996), which was deposited in a fluviolacustrine system associated to distal parts of alluvial fans under a semi-arid to extremely arid climate (Rosa et al. 1991, Weska 2006). This unit has been traditionally referred to the Bauru Group (FrancoRosas et al. 2004, Lacerda Filho et al. 2004), but recent work suggests that all Cretaceous rocks deposited south of the Paraguai fold belt (Almeida 1984) in Mato Grosso should be included in the Parecis Group (Weska 2006). These deposits accumulated on a crust depression formed by tectonic distension events related to the magmatic plume of Trindade (Weska 2006). The basalts of the Paredão Grande Formation, at the base of the Parecis Group, were dated 83.9 $\pm 0.4 \mathrm{Ma}$ (Gibson et al. 1997), i.e. Late Santonian (Gradstein and Ogg 2004). This geophysical and other paleontological evidence (FrancoRosas et al. 2004) suggest a Campanian-Maastrichtian age for the dinosaur fauna of the Parecis Group.

Most dinosaur specimens collected from the Cretaceous of the Paraná Basin (Table II) are isolated teeth and vertebrae (Bertini et al. 1993, Santucci and Bertini 2001, Kellner and Campos 2000, Franco-Rosas 2001, Candeiro et al. 2006a, b), while dinosaur eggs were also recorded in western Minas Gerais ('Triângulo Mineiro' region, Ribeiro 1999, Gobbo-Rodrigues et al. 2005). The majority of these were attributed to Titanosauria (Candeiro et al. 2006a), including those referred to the controversial group "Titanosauridae" (see Salgado et al. 1997, Wilson and Upchurch 2003, Curry Rogers 2005). In the present work, these fragmentary records are all referred to indeterminate Titanosauria. In general, titanosaur species from the Brazilian Cretaceous (Table I, II), i.e. Adamantisaurus mezzalirai, Baurutitan brittoi, Trigonosaurus pricei, Gondwanatitan faustoi, Maxakalisaurus topai, and Uberabatitan ribeiroi, have rarely been analyzed in a phylogenetic context. The most complete study is the doctorate thesis of R.M. Santucci (unpublished data), in which the former three taxa cited above are positioned in the base of a clade that also includes Aeolosaurus, Gondwanatitan, Argentinosaurus, Rinconsaurus and Ampelosaurus. The genus Titanosaurus was also recorded in the Marília Formation of São Paulo and Minas Gerais (Bertini et al. 2001), but the validity of this taxon was contested by Wilson and Upchurch (2003), demanding a revision of this material. A significant occurrence is that of the clade Aeolosaurini (Franco-Rosas et al. 2004). Specimens of this group, referred to as Aeolosaurus and Gondwanatitan, were recovered in the Adamantina Formation of São Paulo (Monte Alto and Álvares Machado areas, Bertini et al. 1999a, Kellner and Azevedo 1999) and Minas Gerais (Prata region, Candeiro et al. 2006b); in the base of the Serra da Galga Member in western Minas Gerais (Bertini et al. 1999b); and in the Cambambe Formation of Mato Grosso (Franco-Rosas et al. 2004). These records allow the correlation with Campanian-Maastrichtian aeolosaur-bearing strata of Argentina (e.g., Angostura Colorada, Allen, Los Alamitos and Bajo Barreal formations, see Casal et al. 2007). Another relevant finding is a partial skeleton referred to Nemegtosauridae from the Adamantina Formation, in the area of Presidente Prudente (Avilla et al. 2005). This clade has been previously recorded only in the Campanian-Maastrichtian of Mongolia (Upchurch 1995, 1999) and alternatively classified within Diplodocoidea (Upchurch et al. 2004) or Titanosauria (Wilson 2005).

The theropod record in the Cretaceous of the $\mathrm{Pa}$ raná Basin (Table I, II) encompasses a number of isolated teeth attributed to Abelisauridae (Bittencourt and Kellner 2002, Candeiro et al. 2002, 2004, 2006a, b), Carcharodontosauridae (Silva and Kellner 1999, Candeiro et al. 2006a), and Deinonychosauria (Bertini et al. 1997, Bertini and Franco-Rosas 2001, Franco-Rosas 2001, 2002). Among these, only the first has further skeletal evidence, i.e., the partial skeleton of Pycnonemosaurus nevesi Kellner and Campos, 2002, a maxillary fragment described by Bertini (1996), and the partial remains (vertebra, femur and phalanges) described by Novas et al. (2008). Other theropod skeletal records include a scapula (Machado et al. 2008) and an ungual phalanx (Novas et al. 2005b) attributed to Maniraptora, and still undescribed Enanthiornithes remains (Alvarenga and Nava 2005). Once proposed spinosaurid occurrences in the Bauru Group were not confirmed (Candeiro et al. 2006a). The abelisauroid fauna of the Bauru Group is coeval to abelisauroid faunas from other parts of Gondwana, i.e., Argentina, Indo-Pakistan, Madagascar, and continental Africa (Fig. 2, 4c) (Bonaparte 1991a, 
Smith and Lamanna 2006, Malkani 2006, Krause et al. 2007, Canale et al. 2009), and alleged European records (Fig. 4c) (Le Loeuff and Buffetaut 1991, Carrano and Sampson 2002, Carrano et al. 2002). Late Cretaceous Enanthiornithes (Chiappe and Walker 2002) are widespread (Fig. 4c) in both Laurasia (North America, Eurasia) and Gondwana (South America and Madagascar). Campanian-Maastrichtian occurrences of carcharodontosaurids based on isolated teeth from both Argentinean and Brazilian strata (Martinelli and Forasiepi 2004, Candeiro et al. 2006a) have been considered dubious by some authors (Canale et al. 2009). However, a preliminary report (Porfiri et al. 2008) of a post-cranial skeleton from the Late Cretaceous of Neuquén Group, Argentina, confirms the presence of post-Cenomanian carcharodontosaurids in Gondwana. Contrasting with the diversified record of Laurasian deinonychosaurs (Norell and Makovicky 2004, Makovicky and Norell 2004), South American occurrences other than isolated teeth from Brazil include a few species from the Late Cretaceous of Argentina (Novas et al. 2008).

\section{DISCUSSION}

Paleogeographic reconstructions of the Middle-Late Triassic depict Pangaea as a nearly continuous supercontinent (Fig. 4a, Scalera 2001, Scotese 2002). In this scenario, dispersal would not be hampered by oceanic barriers (Shubin and Sues 1991, Langer et al. 2010), although large-scale provincialism may result from the establishment of geologic barriers (Coney 1982). Indeed, terrestrial faunal endemism is not conspicuous across Pangaea in the Late Triassic (Benton 1993, Lucas 1998, Langer 2005a), and it is widely known that the tetrapod fauna of the Gondwana II Supersequence is correlated with those from Argentina, India, and southern Africa (Bonaparte 1969, 1973, 1982, Sill 1969, Barberena et al. 1985, Scherer et al. 1995, Lucas 1998, Ray and Chinsamy 2002, Langer 2005b, Kutty et al. 2007), sharing more inclusive but closely related taxa also with Europe and North America (Heckert and Lucas 1998, Langer 2005a).

Much has been argued on the record of the oldest and basal-most dinosauriforms in South America, hinting at the possible origin and early radiation of dinosaurs in southwestern Gondwana (Benton 1988, Langer
2004, Langer et al. 2010). Nesbitt et al. (2009) recently analyzed the premise of a South American protocontinent as the ancestral range for dinosaurs. Using distinct methodologies (Ronquist 1997, Ree and Smith 2008), this was the first objective study to test and corroborate the above mentioned hypothesis. The dataset of Nesbitt et al. (2009) lacks some dinosauriforms from Carnian strata of south Gondwana, as Guaibasaurus and Panphagia, but the inclusion of them probably would reinforce their conclusions (Fig. 2). However, as discussed by several authors (Parker et al. 2005, Nesbitt et al. 2009, Langer et al. 2010), the South American origin hypothesis may be biased by the worldwide record of Ladinian-Carnian terrestrial vertebrates, which mainly encompasses localities from Argentina and Brazil (Rogers et al. 1993, Langer 2005a, b, Langer et al. 2007a). Accordingly, both relative diversity and abundance of basal dinosaurs across Pangaea are probably underestimated.

The distribution patterns of post-Carnian dinosaur faunas across Pangaea, including Laurasia (e.g., Rauhut and Hungerbühler 1998, Irmis 2005, Nesbitt et al. 2007), and their driven biogeographic processes, also remain elusive (Nesbitt et al. 2009), as the detection of vicariance or dispersal depends on distribution data for a wellsampled set of taxa. This is the case of the possible Norian herrerasaurids from North America, which are younger than South American members of this clade. The alleged coeval record of the group in South Africa (Galton 1985) has been refuted (Galton and Van Heerden 1998, Langer 2004, Yates 2007a). Thus, the unambiguous record of herrerasaurid suggests that this clade is restricted to western Pangaea, regardless their phylogenetic position within dinosaurs. Some records from India (Novas et al. 2009a), if confirmed, may expand the known distribution of this clade across south Pangaea. The recent reclassification of the herrerasaurids as basal theropods (Fig. 2, Nesbitt et al. 2009) overcomes the ghost-lineage problem of Theropoda, since sauropodomorphs are recorded since Carnian (Langer et al. 1999, Martinez and Alcober 2009). However, the phylogeny of basal Saurischia is far from consensual (Langer et al. 2010).

Possible Jurassic dinosaurs in Brazil are limited to footprints and trackways from: 1 - Areado Group, in western Minas Gerais, allegedly of Late Jurassic/Early 
TABLE I

List of Mesozoic dinosauriform taxa recorded in Brazil indented by taxonomic hierarchy.

\section{Archosauria sensu Gauthier 1986 \\ cf. Dinosauria \\ Spondylosoma absconditum}

Dinosauriformes sensu Sereno and Arcucci 1994

Silesauridae Langer et al. 2010

Sacisaurus agudoensis

Dinosauria sensu Padian and May 1993

Teyuwasu barberenai

Dinosauria indet.

Ornithischia sensu Butler et al. 2008

cf. Hadrosauridae

Saurischia sensu Langer 2004

cf. Saurischia

Herrerasauridae sensu Langer 2004

Staurikosaurus pricei

Eusaurischia sensu Padian et al. 1999

Saturnalia tupiniquim

Sauropodomorpha sensu Langer 2003

Unaysaurus toletinoi

Sauropoda sensu Yates 2007a

Sauropoda indet.

Nemegtosauridae Upchurch 1995

Nemegtosauridae indet.

Diplodocoidea sensu Wilson 2002

Amazonsaurus maranhensis

Rayososaurus sp.

Diplodocoidea indet.

Titanosauria sensu Upchurch et al. 2004

"Antarctosaurus" brasiliensis

Adamantisaurus mezzalirai

Baurutitan brittoi

Maxakalisaurus topai

Titanosaurus sp.

Trigonosaurus pricei

Uberabatitan ribeiroi

Titanosauria indet.

Andesauridae indet.

Aeolosaurini Franco-Rosas et al. 2004

Aeolosaurus sp.

Gondwanatitan faustoi

Gondwanatitan sp.

Aeolosaurini indet.
Theropoda sensu Gauthier 1986

Guaibasaurus candelariensis

Theropoda indet.

Abelisauridae Bonaparte and Novas 1985

Pycnonemosaurus nevesi

Abelisauridae indet.

Tetanurae Gauthier 1986

Tetanurae indet

Spinosauridae sensu Sereno et al. 1998

Angaturama limai

Irritator challengeri

Spinosauridae indet.

Carcharodontosauridae sensu Sereno et al. 1996

Carcharodontosauridae indet.

Coelurosauria sensu Gauthier 1986

Compsognathidae sensu Holtz et al. 2004

Mirischia asymmetrica

Tyrannoraptora Sereno 1999b

Santanaraptor placidus

Maniraptora Gauthier 1986

Maniraptora indet.

cf. Aves

Deinonychosauria sensu Gauthier 1986

cf. Troodontidae

cf. Dromaeosauridae

cf. Velociraptorinae

Aves sensu Padian and Chiappe 1998

Aves indet.

Enantiornithes indet. 


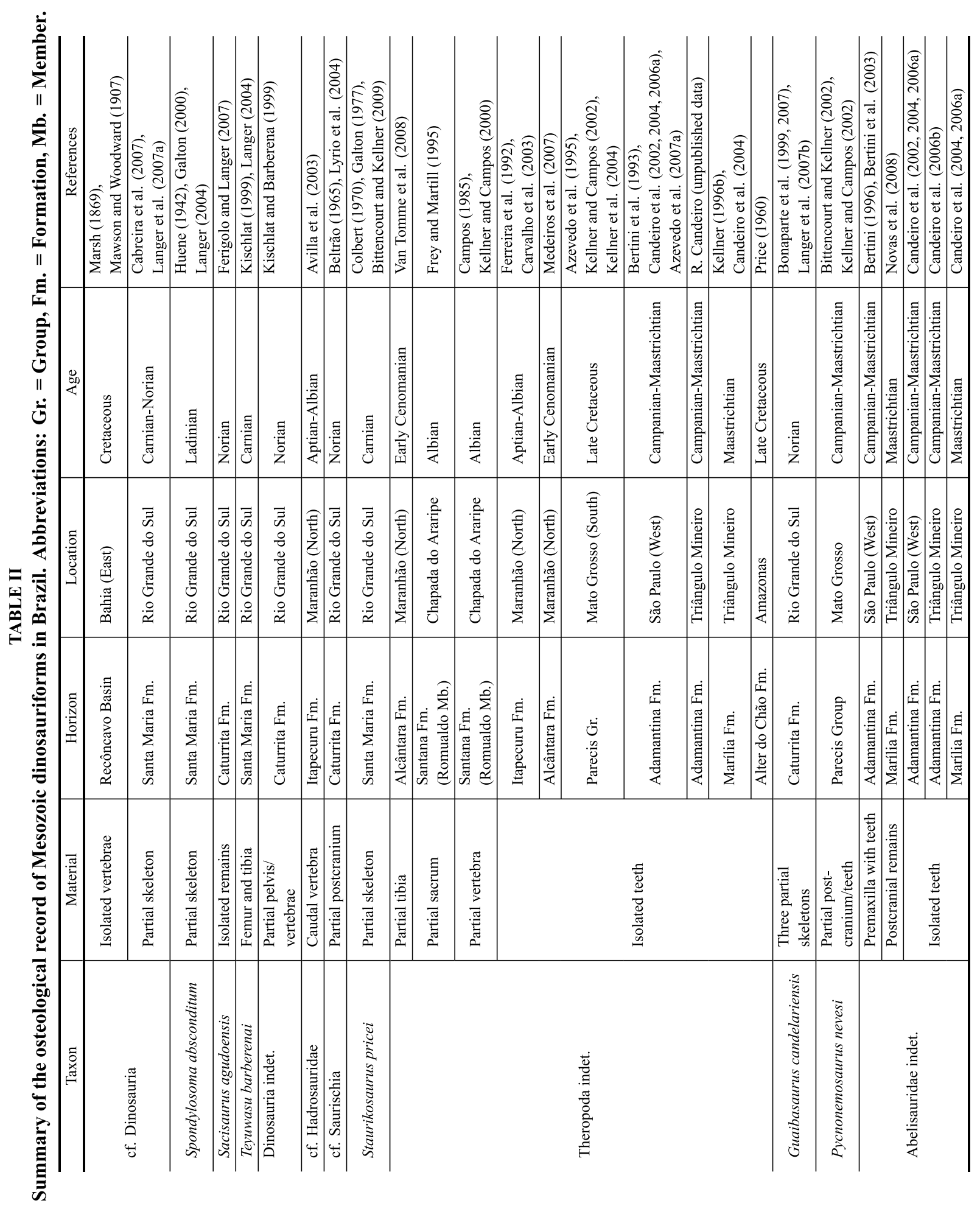




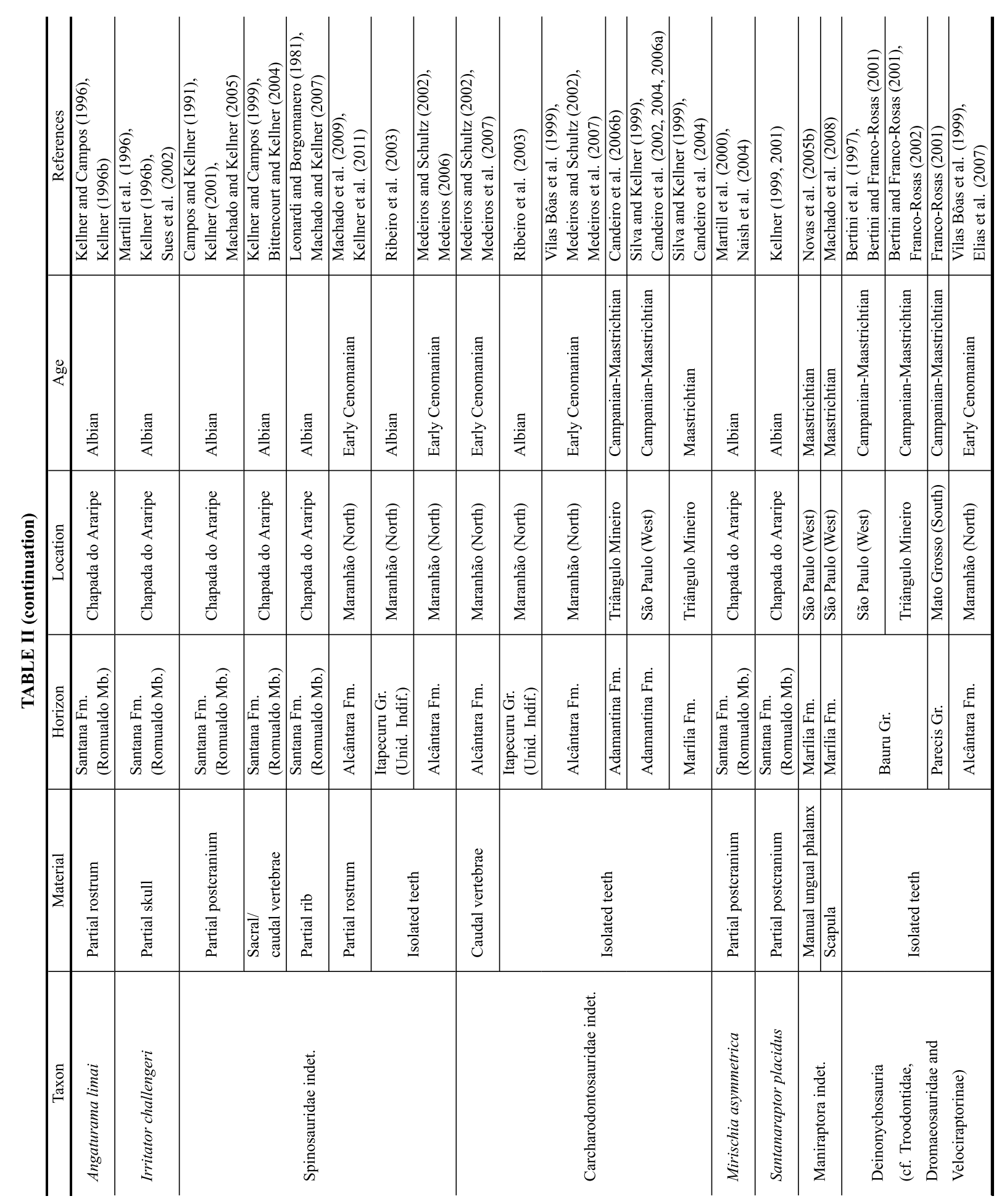




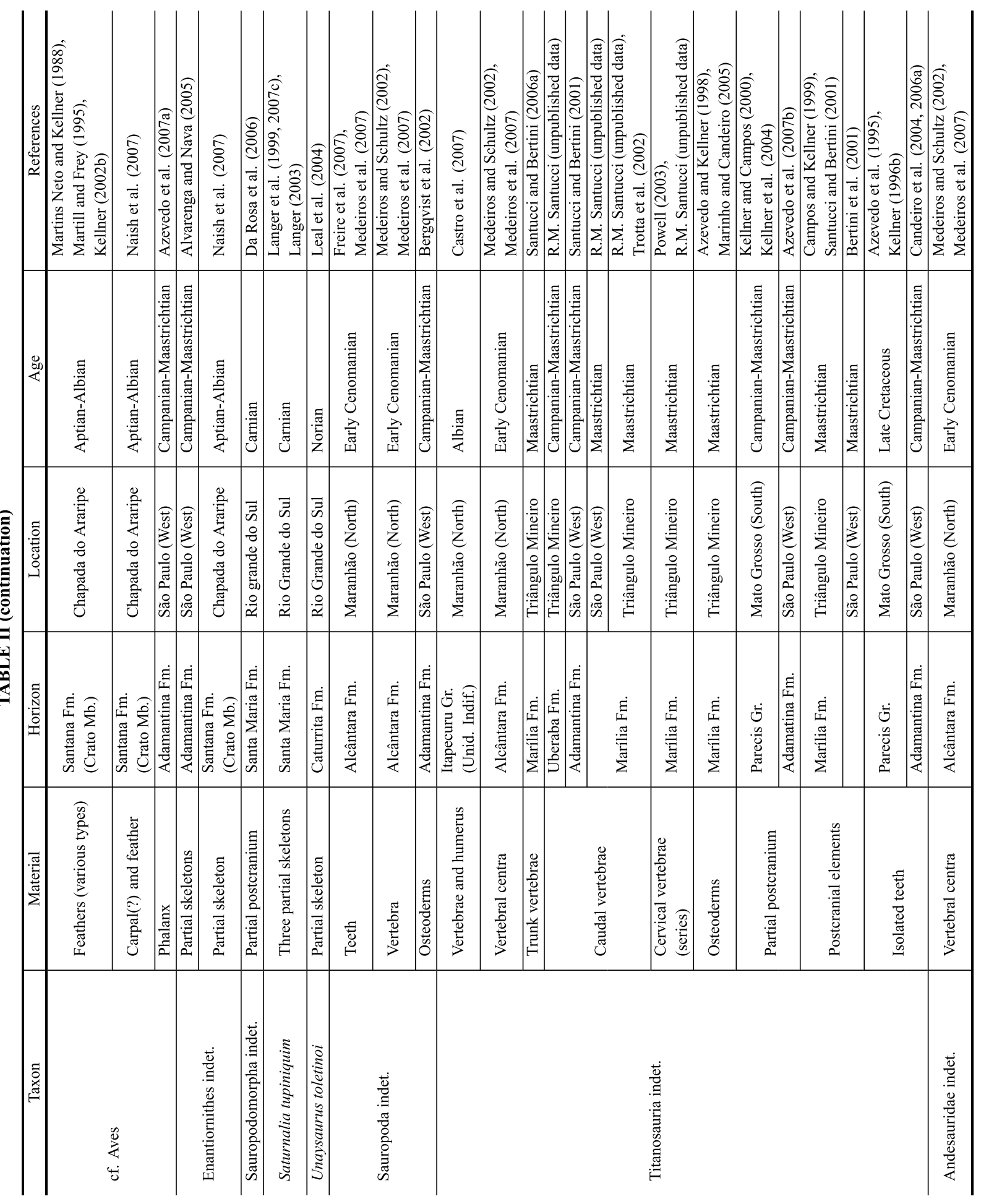




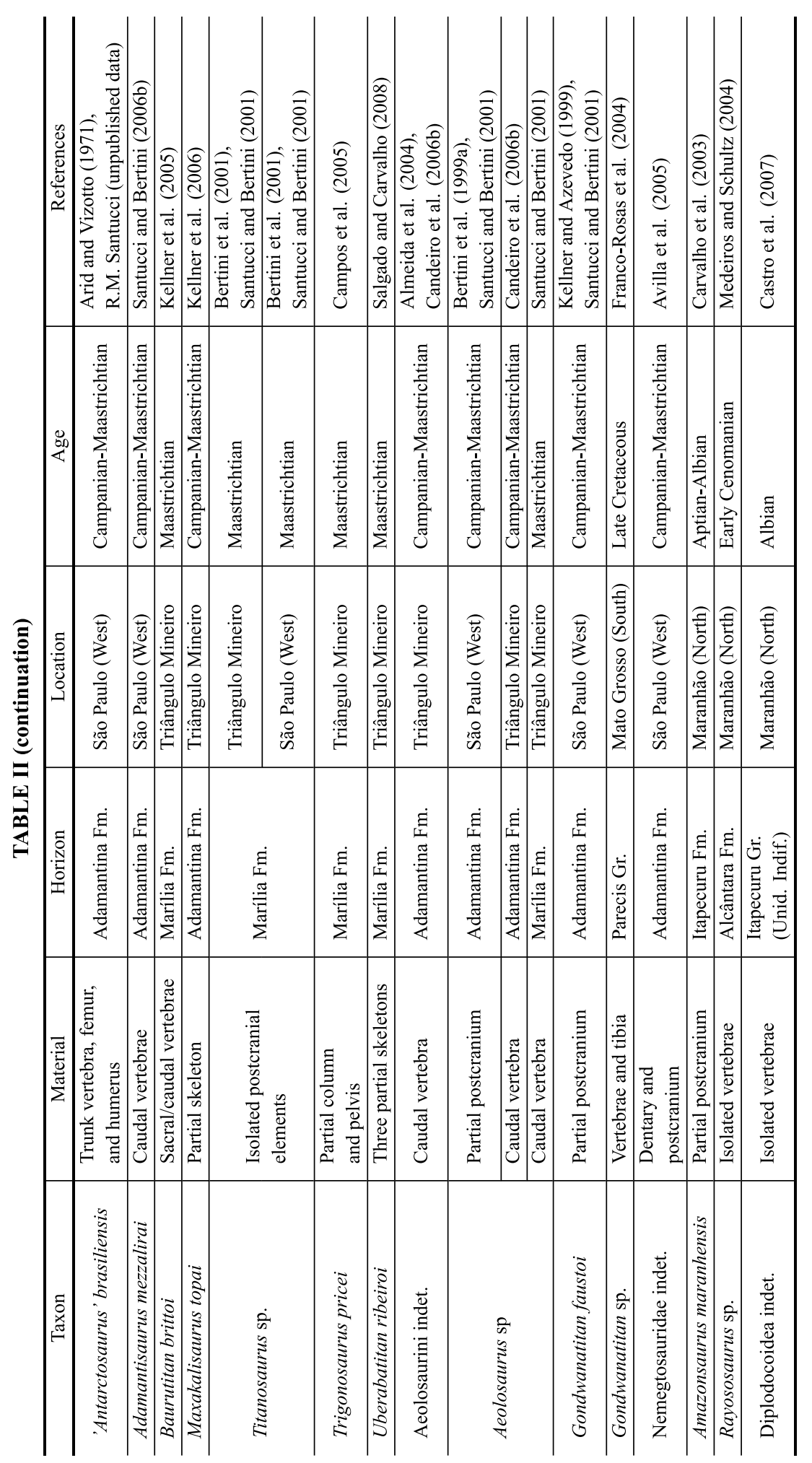


Cretaceous age (Carvalho and Kattah 1998); 2 - Botucatu Formation, Paraná Basin (Leonardi 1980, Leonardi and Oliveira 1990), a massive aeolian sequence of possible Late Jurassic-Early Cretaceous age (Assine et al. 2004) that crops out in an extensive area in east-central South America (Scherer 2000). The ichnofaunas includes possible theropod and ornithopod footprints recovered mainly in São Paulo State (Leonardi 1994, Leonardi et al. 2007, Fernandes and Carvalho 2007). Some authors have noted that the dinosaur fauna from Botucatu Formation is restricted both ecologically, as it is mainly composed of small to medium-sized animals, and taxonomically, with the virtual absence of sauropods (Leonardi 1989, Novas 2007, 2009). The interpretation of the Botucatu Formation as a paleodesert (Assine et al. 2004) suggests that environmental stress could be responsible for this pattern (Novas 2007, 2009). Late Jurassic dinosaur-bearing rocks in Gondwana are rare, with significant records only from the Tendaguru beds, Tanzania, which includes several sauropods, theropods, stegosaurs, and basal iguanodonts (Janensch 1914, Bonaparte et al. 2000, Tykoski and Rowe 2004, Upchurch et al. 2004, Rauhut 2005, Remes 2006, 2007), and the Cañadon Calcáreo Formation, Argentina, with sauropod records (Rauhut et al. 2005, Rauhut and LopezArbarello 2008). Other records (see Novas 2009 for review) include the Lower or Middle Jurassic strata of the La Quinta Formation, Venezuela, with ornithischians and saurischian incomplete specimens (Barrett et al. 2008), La Matilde Formation from Middle or Late Jurassic of Argentina (Leonardi 1989), with theropod footprints (Novas 2009), and Baños del Flaco Formation, Tithonian of Chile (Moreno and Benton 2005), with sauropod tracks. The paucity of Jurassic dinosaurs in Brazil has been discussed under a paleoecological framework (Novas 2007, 2009), and it adds few information from a historical biogeography point of view. Indeed, the same can be said about the ornithischian record, which includes the above-mentioned and additional footprints from the Early Cretaceous of Sousa and Uiraúna-Brejo das Freiras basins, northern Brazil (Leonardi and Carvalho 2002, 2007), and a preliminarily described vertebra from Itapecuru beds (see above) attributed to Hadrosauridae (Avilla et al. 2003). The ornithischian record from Argentina is much richer, consisting of stegosaurids and euornithopods, includ- ing hadrosauroid taxa (Coria and Cambiaso 2007, Novas 2007, 2009). These clades, along with those registered in the Jurassic-Cretaceous of Africa (Galton and Upchurch 2004b, Norman 2004, Norman et al. 2004, Weishampel et al. 2004), probably ranged throughout South America, and could possibly be found in Mesozoic strata of Brazil. Explanations for their paucity include insufficient fieldwork, scarcity of available outcrops due to extensive vegetal covering, and a possible ecological constraint, as ornithischians are rarer herbivorous components in the known Mesozoic Gondwanan terrestrial ecosystems compared to sauropods (Bonaparte 1996, Upchurch and Barrett 2005).

Bonaparte (1986) proposed that the Cretaceous dinosaur faunas from Gondwana and Laurasia might be differentiated by their endemism following the separation of both landmasses in the Jurassic. In general, Laurasia would be dominated by ornithischians and some theropod taxa such as tyrannosauroids, ornithomimids, therizinosaurs and dromaeosaurids, while Gondwana would be inhabited by sauropods, specially titanosaurs (e.g., Bonaparte and Kielan-Jaworowska 1987), and other theropod taxa such as abelisaurids and alvarezsaurids (Bonaparte 1991b, 1996). This proposition has been weakened by novel findings that expand the distribution of several dinosaur clades (Fig. 2). Non-tyrannosaurid tyrannosauroids, possibly including Santanaraptor, are recorded in southern landmasses (Benson et al. 2010), and dromaeosaurids have been recovered in several localities from Gondwana (see above). On the other hand, theropod clades once thought to be endemic of Gondwana were more recently recovered from Laurasian terrains, including carcharodontosaurids from the Early Cretaceous of North America and Europe (Holtz et al. 2004, Sereno and Brusatte 2008), Late Cretaceous of Asia (Brusatte et al. 2010), and alvarezsaurids from the Late Cretaceous of Mongolia and North America (Chiappe et al. 2002). Abelisaurid remains from Laurasia are dubious (e.g., Le Loeuff and Buffetaut 1991, Sampson et al. 1998, but see Pereda-Suberbiola 2009), and titanosaur sauropods have representatives in both landmasses (Taylor and Naish 2007), although they are more common in Gondwanan (Fig. 2, 4b-c) (Upchurch et al. 2004). Naish et al. (2004) suggested the occurrence of some faunal interchange between Europe and South America via Africa in the Early Cretaceous (see 
also Sereno et al. 1998). Indeed, several dinosaur clades recovered in northeastern Brazil in Albian-Cenomanian strata, e.g., Rebbachisauridae, Spinosauridae, Carcharodontosauridae, and Compsognathidae, have older Laurasian records (see above). However, strata of the lowest Cretaceous are rare in northern Gondwana.

Several authors suggested that the similarities between the dinosaur fauna of northeastern Brazil and North Africa (Novas 2007, 2009) in this period may be explained by continuous land connections until the Cenomanian (Calvo and Salgado 1995, Sereno et al. 2003, 2004, Sereno and Brusatte 2008). Evidences supporting this hypothesis (named 'Pan-Gondwana'), include paleogeographic reconstructions (Smith et al. 1994) and shared Cretaceous taxa as the crocodyliforms Araripesuchus (Turner 2006, Sereno and Larsson 2009), Sarcosuchus (Buffetaut and Taquet 1977, 1979, Sereno et al. 2001), and notosuchians (Sereno et al. 2003, Turner 2006); araripemydid turtles (Fuente and Broin 1997, Gaffney et al. 2006); the coelacanthiform Mawsonia (Maisey 1991, Yabumoto and Uyeno 2005); abelisaurid (Sereno et al. 2004, Sereno and Brusatte 2008) and diplodocoid (Calvo and Salgado 1995, Medeiros and Schultz 2004) dinosaurs. However, the separation between Africa and South America is often considered older (Hay et al. 1999, Sampson et al. 1998, Scotese 2002, Krause et al. 2006, 2007), and geologic data from northeastern Brazil point towards the existence of openly marine deposits in Albian times (Petri 1987, Mohriak 2003). In this scenario ('Africafirst' hypothesis), the closer similarity of the turtle and crocodyliform faunas could be explained by the possibility for semi-aquatic forms to disperse across restrict oceanic barriers. Whatever separation date between these landmasses is correct, Upchurch et al. (2002) objectively suggested that vicariance rather than dispersal played a major role in the biogeographic evolution of dinosaurs at least for Middle Jurassic to midCretaceous times. Turner (2004) performed an analysis of crocodyliform biogeography during the Cretaceous and also concluded that vicariance driven by the fragmentation of Gondwana was a major factor affecting the distribution of this clade during mid to Late Cretaceous.

The dataset of Turner (2004) includes several taxa recorded in Brazil as Araripesuchus gomesi, from the Araripe Basin, baurusuchids (Baurusuchus) and peiro- saurids from the Bauru Group. The phylogenetic analysis presented by this author shows $A$. gomesi closer to A. patagonicus, from Argentina, than to A. wegeneri, from Africa. This is congruent with the presence of the sauropod Rayososaurus in mid-Cretaceous strata from both Argentina and Brazil. On the other hand, additional archosaurian records suggest a closer affinity of the northern fauna of the mid-Cretaceous of Brazil with African faunas (Medeiros and Schultz 2002, Novas 2009). This includes the spinosaurids from the Araripe Basin/Itapecuru Group, and the crocodyliform Candidodon itapecuruensis from the Itapecuru Group (Nobre 2004), which is closely related to the African Malawisuchus (Zaher et al. 2006). This conundrum alternatively suggests a closer similarity between eastern and western Gondwanan faunas than previously thought. Accordingly, the close relationship between the crocodyliforms from Itapecuru group with Gondwanan forms (i.e. notosuchians) (Zaher et al. 2006, Kellner et al. 2009), along with the occurrence of peirosaurids and baurusuchids in the Late Cretaceous, reinforces the existence of a vicariant pattern in crocodyliform distribution (Turner 2004). This scenario is also compatible with the distribution of dinosaurs in southern landmasses (Upchurch et al. 2002, Novas 2007, 2009).

The Brazilian fossil record of dinosaurs adds relevant data to the biogeographic comparison with Argentina. Early Cretaceous taxa shared between these areas include diplodocoids, carcharodontosaurids, and titanosaurs. On the contrary, clades recorded in the Araripe and São Luís-Grajaú basins, such as Spinosauridae and Compsognathidae, were not found in chronostratigraphically equivalent strata in Argentina (Novas 2007, 2009), while abelisauroids, with a well-known record in that country, are not recorded in the Aptian-Cenomanian of Brazil. This pattern may reflect either the paucity of the fossil record, inaccessibleness to fossil specimens due to vegetal covering, insufficient fieldwork, or endemism, although evidence supporting the latter is weak. The Late Cretaceous from both areas exhibits a rather similar dinosaur fauna, including carcharodontosaurids and aeolosaurine titanosaurs, even at a generic level, i.e., Aeolosaurus (see below).

Due to its Gondwanan distribution (Fig. 3c), abelisauroids played a major biogeographic role since their first discovery (Bonaparte and Novas 1985). The oc- 
currence of more derived forms of this clade (Carnotaurinae sensu Sereno et al. 2004, see also Carrano and Sampson 2008) in South America, Indo-Pakistan, and Madagascar leaded some authors (Sampson et al. 1998) to suggest that abelisaurids might have radiated across Gondwana after the separation of continental Africa in the Early Cretaceous (Krause et al. 2007). Yet, recent records of basal abelisauroids in the Early Cretaceous of Niger (Sereno et al. 2004, Sereno and Brusatte 2008), along with fragmentary material from the Aptian-Albian of Libya (Smith and Dalla Vecchia 2006), Cenomanian of Morocco (Mahler 2005), and Maastrichtian of Egypt (Smith and Lamanna 2006), indicate a wider distribution of this group in southern landmasses than previously thought. These findings suggest a later separation of continental Africa from Gondwana ('Pan-Gondwana' model), and the absence of carnotaurines in northern Africa in the Late Cretaceous could be explained by the incompleteness of the fossil record (Sereno and Brusatte 2008). However, recent findings suggest that carnotaurines are restricted to Gondwana and at least one clade within it (Brachyrostra) is endemic to South America (Canale et al. 2009). The recent discovery of a Megaraptor-like theropod in the Early Cretaceous of Australia is congruent with a connection between South America and Australia until the Late Cretaceous (Krause et al. 2006), but it is uncertain if the separation of Africa occurred earlier than this period (Sereno et al. 2004).

The sauropod fossil record in Brazil (Table I, II) is also relevant for paleobiogeographic studies because of its rich titanosaur record. In the context of some phylogenetic hypotheses (Wilson 2002, Upchurch et al. 2004, Curry Rogers 2005), the Late Cretaceous cosmopolitanism of this clade (Fig. 4b-c) cannot be explained only by cladogenesis associated with the splitting of Pangaea. For some authors (e.g., Bonaparte 1984, Sullivan and Lucas 2000), the Maastrichtian record of the titanosaur Alamosaurus in North America (Montellano-Ballesteros 2003, Upchurch et al. 2004) is congruent with a land connection with South America in the Late Cretaceous (Simpson 1950, 1978), which would also be responsible for the presence of hadrosaurids and ankylosaurs in southern latitudes (Bonaparte et al. 1984, McCarthy 2005, Coria and Cambiaso 2007).

The Late Cretaceous tetrapod fauna of the Bauru Group has often been considered endemic, either at a generic level (Bertini et al. 1993) or for small-bodied animals relative to sauropod dinosaurs (e.g., crocodylomorphs and turtles, Santucci and Bertini 2001). These alleged taxonomic and/or ecological partitioning may be related to the formation of biogeographic barriers at the borders of the 'basin' originated with the lithostatic load of the basalt floods referred to as the Serra Geral Formation (Santucci and Bertini 2001). However, the existence of geologic barriers at the borders of Bauru Group is questionable (see Milani 2001). Besides, no tetrapod taxon is endemic to the Bauru Group at a suprageneric level, and even genera such as Aeolosaurus, Peirosaurus, Roxochelys, plus baurusuchids closely related to Brazilian forms are recorded in Argentinean strata (Gasparini 1972, Broin 1991, Gasparini et al. 1991, Riff and Kellner 2001, Franco-Rosas et al. 2004). In addition, taxa recorded only in the Bauru Group are closely related to forms recorded in widespread localities across southern landmasses (Franco-Rosas et al. 2004, Carvalho et al. 2004, Turner and Calvo 2005, Zaher et al. 2006, França and Langer 2006, Evans et al. 2008). Although less diverse and abundant than some faunas of equivalent age in South America (e.g., Neuquina Basin, Novas 2009), the dinosaur assemblages of the Bauru Group is rather similar to the Late Cretaceous assemblages from other parts of Gondwana, especially Argentina.

\section{CONCLUSIONS}

i) The dinosaur record of the Brazilian Mesozoic, although rather incomplete, has added significant data to biogeographic studies. This record is incongruent with the continental dimension of the country, and the scarcity of Jurassic and ornithischian forms may be related to deficient fieldwork, inaccessibleness to the fossiliferous strata, lack of strata of appropriate age, or a true biogeographic pattern. On the other hand, most descriptive works (80\%) are concentrated in the last decade, suggesting further increase of this record in the near future.

ii) Triassic dinosaur faunas from south Brazil are specially correlated with others from south Gondwana, in a dispersal scenario favored by the lack of extensive oceanic barriers. An exception to this cosmopolitanism is the Herrerasauridae, a clade prob- 
ably restricted to western Pangaea (i.e., South and probably North America).

iii) Various biogeographic models have been proposed to explain the distribution of Cretaceous dinosaur faunas in Gondwana. However, some of them do not incorporate vicariance as a fundamental process of biogeographic evolution, and barely take into consideration the scarcity of the fossil record of several key areas, as northern Brazil and Africa. Nonetheless, the 'Pan-Gondwana' hypothesis is partially supported by the faunal similarities among Argentina, Brazil and North Africa until the Cenomanian. Recent works suggests that vicariance driven by the fragmentation of Gondwana was an important process of dinosaurs and crocodyliform biogeographic evolution in the Cretaceous, which is consistent with the fossil record of these groups in South America. More conspicuous similarities in dinosaur and crocodyliform faunas from South America and India-Madagascar rather than continental Africa may be result of land connection between these areas well into the Late Cretaceous.

iv) The comparable distribution of non-avian dinosaurs in Brazil and Argentina is noted from the Late Triassic to Late Cretaceous. However, some peculiarities as the absence of spinosaurids and compsognathids in Argentina, and ornithischians and abelisauroids in the Early Cretaceous of Brazil remain to be fully clarified. In this context, the endemism of the Bauru Group fauna, as proposed by some authors, is jeopardized by the occurrence of several of its taxa in various localities in South America and other Gondwanan areas.

\section{ACKNOWLEDGMENTS}

The authors wish to thank Ricardo Weska and Manuel Alfredo de Medeiros for sharing information on some Cretaceous deposits from Brazil, and Alex Kellner for the invitation to contribute in this volume. This project was funded by Coordenação de Aperfeiçoamento de Pessoal de Nível Superior (CAPES), with a doctorate fellowship to JSB, Conselho Nacional de Desenvolvimento Científico e Tecnológico (CNPq), and Fundação de Amparo à Pesquisa do Estado de São Paulo (FAPESP).

\section{RESUMO}

O registro osteológico de dinossauros no Mesozóico brasileiro está restrito a rochas triássicas do Rio Grande do Sul e estratos cretáceos de várias partes do país. Isto inclui 21 espécies nominais, sendo duas referidas como nomina dubia, e 19 consensualmente classificadas como dinossauros. Oito táxons supraespecíficos adicionais baseados em material fragmentado e diversas pegadas são conhecidos no Brasil. De fato, a maior parte dos espécimes é composta de dentes isolados e vértebras. Apesar do aumento em trabalhos de campo na última década, não há exemplar esqueletal de dinossauro no Jurássico brasileiro, e é escassa a evidência de Ornithischia. Faunas dinossaurianas aqui registradas são em geral correlatas com aquelas da Pangéia durante o Mesozóico. No Triássico Superior, há uma correspondência próxima com a Argentina e outras regiões sul-gondwânicas. Faunas do Cretáceo médio do nordeste brasileiro são semelhantes às dos depósitos coevos do norte da África e Argentina. Registros de espinossaurídeos no hemisfério sul estão restritos à África e Brasil, enquanto abelissaurídeos não são conhecidos no Cretáceo Inferior deste último. Assembleias de dinossauros da região sul e central do Brasil são endêmicas apenas em nível de gênero e, mais conspicuamente, espécie, compartilhando táxons proximamente relacionados com assembleias da Argentina, Indo-Paquistão, e, num menor grau, África continental.

Palavras-chave: Brasil, Dinosauria, Triássico, Jurássico, Cretáceo, paleobiogeografia.

\section{REFERENCES}

Agnolín FL and Martinelli AG. 2007. Did oviraptorosaurs (Dinosauria:Theropoda) inhabit Argentina? Cretaceous Res 28: 785-790.

Alcober OA And Martinez RN. 2010. A new herrerasaurid (Dinosauria, Saurischia) from the Upper Triassic Ischigualasto Formation of northwestern Argentina. ZooKeys 63: 55-81.

AllPORT S. 1860. On the discovery of some fossil remains near Bahia in South America. Q J Geol Soc London 16: 263-268.

AlMeIDA FFM. 1984. Província Tocantins, setor sudoeste. In: Almeida FFM ANd Hasui Y (Eds), Pré-cambriano do Brasil. São Paulo: Edgar Blücher, p. 265-281.

Almeida EB, Avilla LS and Candeiro CRA. 2004. Restos caudais de Titanosauridae da Formação Adamantina (Turoniano-Santoniano), sítio do Prata, estado de Minas Gerais, Brasil. Rev Bras Paleontol 7: 239-244. 
Alvarenga H AND NAVA WR. 2005. Aves Enantiornithes do Cretáceo Superior da Formação Adamantina do estado de São Paulo, Brasil. In: CONGREsso LATINoamericano de Paleontologia de Vertebrados, 2, Rio de Janeiro, Boletim de Resumos, Rio de Janeiro: Museu Nacional, $20 \mathrm{p}$.

Andreis RR, Bossi GE And Montardo DK. 1980. O Grupo Rosário do Sul (Triássico) no Rio Grande do Sul. In: Congresso Brasileiro de Geologia, 31, Camboriú, Anais, Camboriú SBGeo, p. 659-673.

ARAI M. 1999. A transgressão marinha mesocretácea: sua implicação no paradigma da reconstituição paleogeográfica do Cretáceo no Brasil. In: SIMPÓSIO SOBRE O CRETÁCEO Do BRAsil, 5, Serra Negra, Boletim, Rio Claro, UNESP, p. 577-582.

ARAi M AND CoIMBRA JC. 1990. Análise paleoecológica do registro das primeiras ingressões marinhas na Formação Santana (Cretáceo Inferior da Chapada do Araripe). In: Simpósio SOBRE A BACIA Do ARARIPE E BACIAS Interiores do Nordeste, 1, Crato, Atas, Crato, URCA, p. 225-239.

ARID FM AND VizotTo LD. 1971. Antarctosaurus brasiliensis, um novo saurópode do Cretáceo Superior do sul do Brasil. In: Congresso Brasileiro de Geologia, 25, São Paulo, Anais, São Paulo, SBG, p. 297-305.

Assine ML. 1992. Análise estratigráfica da Bacia do Araripe, nordeste do Brasil. Rev Bras Geocienc 22: 289-300.

Assine ML, Piranha JM And CARneiro CDR. 2004. Os paleodesertos Pirambóia e Botucatu. In: MANTESSO Neto V, BARTorelli A, CARneiro CDR AND BRito Neves BB (Orgs), Geologia do continente sul-americano: evolução da obra de Fernando Flávio Marques de Almeida. São Paulo, Beca, p. 77-92.

Avilla LS, CANDEIRo CRA AND ABRAntes EAL. 2003. Ornithischian remains from the Lower Cretaceous of Brazil and its paleobiogeographic implications. In: SIMPósio Brasileiro de Paleontologia de VerteBRADOs, 3, Rio de Janeiro, Livro de Resumos, Rio de Janeiro, UERJ, 14 p.

Avilla LS, Candeiro CRA And Nava WR. 2005. An unusual sauropod dentary from the Adamantina Formation (Turonian-Santonian) of São Paulo, Brazil, with some comments on its relationships and paleobiogeography. Congresso Latino-americano de Paleontologia de Vertebrados, 2, Rio de Janeiro, Boletim de Resumos, Rio de Janeiro, Museu Nacional, p. 42-43.

AzeVEdo RPF, VAsconcellos PL, CANDEIRo CRA AND BERGQVIST LP. 2007a. Restos microscópico de vertebrados fósseis do Grupo Bauru (Neocretáceo), no oeste do estado de São Paulo, Brasil. In: CARVAlHo IS, Cassab RCT, Schwanke C, Carvalho MA, FerNANDEs ACS, Rodrigues MAC, CARVAlHo MSS, Arai M ANd Oliveira MEQ (Eds), Paleontologia: Cenários de Vida. Rio de Janeiro: Interciência 1: 541549.

AzEvedo RP, CANDEIRo CRA AND BERGQVist LP. 2007b. Primeiro Registro de Pós-cranianos de Titanosauria (Sauropoda) no Município de Alfredo Marcondes/ SP, Formação Adamantina (Turoniano-Santoniano), Bacia Bauru. Anuário Inst Geocienc 30: 112-118.

Azevedo SAK, Campos DA, Kellner AWA, Silva VG AND CARVAlho LB. 1995. Vertebrados cretáceos do Morro do Cambambe, Mato Grosso. In: Congresso Brasileiro de Paleontologia, 14, Uberaba, Atas... Rio de Janeiro, SBP, p. 4-5.

Azevedo SAK AND Kellner AWA. 1998. A titanosaurid (Dinosauria, Sauropoda) osteoderm from the Upper Cretaceous of Minas Gerais, Brazil. Bol Mus Nac Geol 44: $1-6$.

Azevedo SAK, Schultz CL And Barberena MC. 1990. Novas evidências bioestratigraficas e paleoecológicas da evolução explosiva dos rincossauros do Triássico. Paula-Coutiana 4: 23-33.

BÁEz AM AND MARsicano CA. 2001. A heterodontosaurid ornithischian dinosaur from the Upper Triassic of Patagonia. Ameghiniana 38: 271-279.

BAPtista MB, BRAUN OPG AND CAMPos DAC. 1984. Léxico Estratigráfico do Brasil. Brasília, CPRM, 560 p.

BARBERENA MC. 1977. Bioestratigrafia preliminar da Formação Santa Maria. Pesquisas 7: 111-119.

Barberena MC, AraúJo DC and Lavina EL. 1985. Late Permian and Triassic tetrapods of Southern Brazil. Nat Geo Res 1: 5-20.

Barrett PM, Butler RJ, Novas FE, Moore-Fay SC, Moody JM, Clark JM ANd SÁnCHEZ-VillaGRA MR. 2008. Dinosaur remains from the La Quinta Formation (Lower or Middle Jurassic) of the Venezuelan Andes. Paläontol Z 82: 163-177.

Beltrão R. 1965. Paleontologia de Santa Maria e São Pedro do Sul, RS, Brasil. Bol Inst Ci Nat UFSM 2: 1-151.

BENSON RBJ, BARRETT PM, RiCH TH AND VICKERSRICH P. 2010. A southern tyrant reptile. Science 327: 1613.

Benton MJ. 1983a. Dinosaur success in the Triassic - a noncompetitive ecological model. Q Rev Biol 58: 29-55. 
Benton MJ. 1983b. The Triassic reptile Hyperodapedon from Elgin, functional morphology \& relationships. Phil Tr R Soc Lond B: 1-322.

Benton MJ. 1988. The origins of the dinosaurs. Mod Geol 13: 41-56.

BEnton MJ (ED). 1993. The fossil record 2. London: Chapman and Hall, 845 p.

Bergqvist LP, Torres SR And Avilla LS. 2002. Short note on dinosaur osteoderms from the Adamantina Formation, Upper Cretaceous of São Paulo State, Brazil. Bol Mus Nac Geol 62: 1-5.

BERTINI RJ. 1996. Evidências de Abelisauridae (Carnosauria : Saurischia) do Neocretáceo da Bacia do Paraná. In: Simpósio sobre o Cretáceo do Brasil, 4, Águas de São Pedro/Rio Claro, Boletim, Rio Claro, UNESP, p. $267-271$.

BERTINi RJ AND CAMpos DA. 1987. Restos de um grande saurópodo em Monte Alto, Estado de São Paulo. In: CONGresso Brasileiro de Paleontologia, 10, Rio de Janeiro, Boletim, Rio de Janeiro, SBP, 10 p.

Bertini RJ, Franco AC, TOledo CEV AND CAMpos ACA. 1997. Theropod teeth from the Adamantina Formation, Upper Cretaceous of São Paulo State. Analysis of dental morphology. In: CONGRESSO BRASILEIRO DE Paleontologia, 15, São Pedro, Boletim de Resumos, São Pedro, UNESP, 103 p.

BERTINI RJ AND FRANCO-Rosas AC. 2001. Scanning electronic microscopic analysis on Maniraptoriformes teeth from the Upper Cretaceous of Southeastern Brazil. J Vertebr Paleontol 21(Suppl 3): 33A.

Bertini RJ, Marshall LG, Gayet M And Brito P. 1993. Vertebrate faunas from the Adamantina and Marília (Upper Bauru Group, Late Cretaceous, Brazil) in their stratigraphic and paleobiogeographic context. N Jahrb Geol Paläont M 188(1): 71-101.

BERTINI RJ, SANTUCCI RM AND CAMPOS ACA. 1999a. First occurrence of Aeolosaurus (Sauropoda, Titanosauridae) in Bauru Group of the Paraná Basin, Brazil. In: Congresso Brasileiro De Paleontologia, 16, Crato, Boletim de Resumos, Crato, SBP, p. 27-28.

Bertini RJ, SANTUCCi RM AND CAMpos ACA. 2001. Titanossauros (Sauropoda: Saurischia) no Cretáceo Superior continental (Formação Marília, Membro Echaporã) de Monte Alto, Estado de São Paulo, e correlação com formas associadas do Triângulo Mineiro. Geocienc 20(12): 93-103.

Bertini RJ, SANTUCCI RM, MANZini FF, BRANDT Neto M AND Moreno DP. 2003. Estado atual dos conheci- mentos bióticos, ecológicos e biocronológicos dos vertebrados da Bacia Bauru, Cretáceo Superior continental do Sudoeste do Brasil. Perspectivas investigativas futuras. In: Simpósio Brasileiro de PaleontoloGia De Vertebrados, 3, Rio de Janeiro, Livros de Resumos, Rio de Janeiro, UERJ, p. 16-17.

BERTINi RJ, SANTUCCI RM AND Ribeiro LCB. 1999 b. O titanossáurido Aelosaurus sp. (Saurischia, Sauropoda) no membro Serra da Galga da Formação Marília, Grupo Bauru do Triângulo Mineiro. In: Simpósio de GeOloGia do Sudeste, 6, São Pedro, Boletim de Resumos, Rio Claro, UNESP, 78 p.

BEURLEN K. 1971. As condições ecológicas e faciológicas da Formação Santana na Chapada do Araripe (nordeste do Brasil). An Acad Bras Cienc 43: 411-415.

Bittencourt JS. 2008. Triassic dinosaurs from Brazil: species and clades of a diversified saurischian fauna. In: Congreso LatinoAmericano de PAleontología DE Vertebrados, 3, Neuquén, Libro de Resúmenes, Neuquén, UNC, 24 p.

Bittencourt JS And Kellner AWA. 2002. Abelisauria (Theropoda, Dinosauria) teeth from Brazil. Bol Mus Nac Geol 63: 1-8.

Bittencourt JS AND Kellner AWA. 2004. On a sequence of sacrocaudal theropod dinosaur vertebrae from the Lower Cretaceous Santana Formation, northeastern Brazil. Arq Mus Nac 62: 309-320.

Bittencourt JS And Kellner AWA. 2009. The anatomy and phylogenetic position of the Triassic dinosaur Staurikosaurus pricei Colbert, 1970. Zootaxa, p. 1-56.

BitTencourt J AND LANGer M. 2009. Silesaurids: clades, grades, dinosaurs? J Vertebr Paleontol 29(Suppl 3): 65A.

BLAKEY R. 2006. Mollewide plate tectonic maps. NAU Geology. <http://jan.ucc.nau.edu/ rcb7/mollglobe.html>

BonAparte JF. 1969. Los Tetrapodos Triasicos de Argentina. In: Gondwana Symposium, 1, Mar del Plata, Unesco, p. 307-325.

BOnAPARTE JF. 1973. Edades reptil para el Triásico de Argentina y Brasil. In: Congreso Geologico ARGENTINO, 5, Córdoba, Actas 3: 93-129.

BONAPARTE JF. 1982. Faunal replacement in the Triassic of South America. J Vertebr Paleontol 2: 362-371.

BONAPARTE JF. 1984. El intercambio faunistico de vertebrados continentales entre América del Sur y del Norte a fines del Cretácico. In: CONGRESO LATINO-AMERICANO DE Paleontología, 3, Mexico, DF, Actas, p. 38-45.

BONAPARTE JF. 1986. History of the terrestrial Cretaceous vertebrates of Gondwana. In: CONGRESo ARGENTINO 
de Paleontologia y Bioestratigrafia, 4, Mendoza, Actas 2: 63-95.

BONAPARTE JF. 1991a. The Gondwanian theropod families Abelisauridae and Noasauridae. Hist Biol 5: 1-25.

BONAPARTE JF. 1991b. Los vertebrados fósiles de la formación Rio Colorado, de la ciudad de Neuquén y cercanias, Cretácico Superior, Argentina. Rev Mus Arg Ci Nat "Bernardino Rivadavia" 4(3): 1-123.

Bonaparte JF. 1996. Cretaceous tetrapods of Argentina. Münchner Geowiss Abh 30: 73-130.

Bonaparte JF, Brea G, Schultz CL AND Martinelli AG. 2007. A new specimen of Guaibasaurus candelariensis (basal Saurischia) from the Late Triassic Caturrita Formation of southern Brazil. Hist Biol 19: 73-82.

BONAPARTE JF AND CORIA RA. 1993. Un nuevo y gigantesco sauropodo titanosaurio de la Formación Río Limay (Albiano-Cenomaniano) de la Provincia del Neuquén, Argentina. Ameghiniana 30: 271-282.

Bonaparte JF, Ferigolo J And Ribeiro AM. 1999. A new early Late Triassic saurischian dinosaur from Rio Grande do Sul State, Brazil. Nat Sci Mus Monogr 15: 89-109.

Bonaparte JF, HeInRICH WD AND WILd R. 2000. Review of Janenschia Wild, with the description of a new sauropod from the Tendaguru beds of Tanzania and a discussion on the systematic value of procoelous caudal vertebrae in the sauropoda. Paläeontogr Abt A 256: 25-76.

BonAPARTE JF AND KIELAN-JAWOROWSKA K. 1987. Late Cretaceous dinosaur and mammal faunas of Laurasia and Gondwana. Occas Pap Royal Tyrrell Mus Palaeo 3: 24-29.

Bonaparte JF AND Novas FE. 1985. Abelisaurus comahuensis, n. g., n. sp. Carnosauria del Cretácico Tardio de Patagonia. Ameghiniana 21: 259-265.

Bonaparte JF, RAnchi MR, Powell JE And SEPUlVEDA EG. 1984. La Formación Los Alamitos (Campaniano-Maastrichtiano) del sudeste de Río Negro, con descripción de Kritosaurus australis n. sp. (Hadrosauridae). Significado paleogeografico de los vertebrados. Rev Asoc Geol Argentina 39: 284-299.

BROIN F. 1991. Fossil turtles from Bolivia. In: SURUCO RS (Ed), Fósiles y Facies de Bolivia. Rev Tec Yacim Petrol Fisc Bolívia 12: 509-527.

Brusatte SL, Chure DJ, Benson RBJ And XU X. 2010. The osteology of Shaochilong maortuensis, a carcharodontosaurid (Dinosauria: Theropoda) from the Late Cretaceous of Asia. Zootaxa 2334: 1-46.
Brusatte SL And Sereno PC. 2007. A new species of Carcharodontosaurus (Dinosauria: Theropoda) from the Cenomanian of Niger and a revision of the genus. $\mathrm{J}$ Vertebr Paleontol 27: 902-916.

Brusatte SL And Sereno PC. 2008. Phylogeny of Allosauroidea (Dinosauria : Theropoda): Comparative analysis and resolution. J Syst Palaeontol 6: 155-182.

Buffetaut E. 2007. The spinosaurid dinosaur Baryonyx (Saurischia, Theropoda) in the Early Cretaceous of Portugal. Geol Mag 144: 1021-1025.

Buffetaut E AND INGAVAT R. 1986. Unusual theropod dinosaur teeth from the Upper Jurassic of Phu Wiang, northeastern Thailand. Rev Paleobiol 5: 217-220.

Buffetaut E, Martin V, Sattayarak N and SuteeTHORN V. 1995. The oldest dinosaur from Southeast Asia: a prosauropod from the Nam Phong Formation (Late Triassic) of northeastern Thailand. Geol Magazine 132: 739-742.

Buffetaut E And Ouaja M. 2002. A new specimen of Spinosaurus (Dinosauria, Theropoda) from the Lower Cretaceous of Tunisia, with remarks on the evolutionary history of the Spinosauridae. Bull Soc Geol France 173: 415-421.

Buffetaut E, Suteethorn V, Tong Hy and Amiot R. 2008. An Early Cretaceous spinosaurid theropod from southern China. Geol Mag 145: 745-748.

Buffetaut E And Taquet P. 1977. The giant crocodilian Sarcosuchus in the Early Cretaceous of Brazil and Niger. Palaeontology 20: 203-208.

Buffetaut E AND TAQuet P. 1979. Early Cretaceous terrestrial crocodilian and the opening of the South-Atlantic. Nature 280: 486-487.

Butler RJ, Smith RMH and Norman DB. 2007. A primitive ornithischian dinosaur from the Late Triassic of South Africa, and the early evolution and diversification of Ornithischia. Proc R Soc London B 274: 2041-2046.

Butler RJ, UpChurch P AND Norman DB. 2008. The phylogeny of the ornithischian dinosaurs. J Syst Paleontol 6: $1-40$.

Butler RJ, UpChurch P, NoRman DB AND PARish JC. 2006. A biogeographical analysis of the ornithischian dinosaurs. In: BARRETT PM AND EVANS SE (Eds), International Symposium on Mesozoic Terrestrial Ecosystems and Biota, 9, Manchester, Abstracts and Proceedings, London, The Natural History Museum, p. 13-16.

Cabreira SF, Lisboa VHM, Silva JMF, Silva LR, Santos PM, Amaral P AND Weigert K. 2007. Dis- 
covery of a primitive neotheropod from Santa Maria Formation. Triassic Carnian age. Paleontologia em Destaque 57: 45.

Calvo JO, Porfiri JD And Kellner AWA. 2004. On a new maniraptoran dinosaur (Theropoda) from the Upper Cretaceous of Neuquén, Patagonia, Argentina. Arq Mus Nac 62: 549-566.

Calvo JO And SAlgado L. 1995. Rebbachisaurus tessonei sp. nov. a new Sauropoda from the Albian-Cenomanian of Argentina; new evidence on the origin of the Diplodocidae. Gaia 11: 13-33.

CAMPos DA. 1985. Ocorrência de um novo arcossauro na Chapada do Araripe. An Acad Bras Cienc 57: 140-141.

Campos DA And Kellner AWA. 1991. Dinosaurs of the Santana Formation with comments on other Brazilian occurrences. In: MAISEY JG (Ed), Santana fossils: an illustrated atlas. Neptune: T.F.H, p. 372-375.

CAMPos DA AND Kellner AWA. 1999. On some sauropod (Titanosauridae) pelves from the continental cretaceous of Brazil. Nat Sci Mus Monogr 15: 143-166.

Campos DA, Kellner AWA, Bertini RJ And SAntuCCI RM. 2005. On a titanosaurid (Dinosauria, Sauropoda) vertebral column from the Bauru Group, Late Cretaceous of Brazil. Arq Mus Nac 63: 565-593.

Canale J, Scanferla C, Agnolin F and Novas F. 2009. New carnivorous dinosaur from the Late Cretaceous of NW Patagonia and the evolution of abelisaurid theropods. Naturwissenschaften 96: 409-414.

Candeiro CRA, Abranches CT, Abrantes EA, AvilLA LS, Martins VC, Moreira A, Torres S AND BERGQVIST LP. 2004. Dinosaurs remains from western São Paulo state, Brazil (Bauru Basin, Adamantina Formation, Upper Cretaceous). J S Am Earth Sci 18: 1-10.

CANDEIRo CRA, Martinelli AG, Avilla LS AND Rich TH. 2006a. Tetrapods from the Upper Cretaceous (Turonian-Maastrichtian) Bauru Group of Brazil: a reappraisal. Cretaceous Res 27: 923-946.

CANDEIRo CRA, SAntos AR, BergQvist LP, Ribeiro LCB And Apesteguia S. 2008. The Late Cretaceous fauna and flora of the Uberaba area (Minas Gerais State, Brazil). J S Am Earth Sci 25: 203-216.

CAndeIro CRA, SAntos AR, Rich TH, Marinho TS AND Oliveira EC. 2006b. Vertebrate fossils from the Adamantina Formation (Late Cretaceous), Prata paleontological district, Minas Gerais State, Brazil. Geobios 39: 319-327.

Candeiro Cra, Torres S, Moreira A, Martins VC, Abrantes EA, Avilla LS, Abranches CT And
BERgQVist LP. 2002. Novos achados de Dinosauria no oeste do estado de São Paulo, na Formação Adamanina (Bacia Bauru) Cretáceo Superior. In: SIMPÓSIO DE Bacia Cretácicas Sul-Americanas, 6, São Pedro, Boletim, p. 409-413.

Canudo JI And Salgado L. 2003. Los dinosaurios del Neocomiense (Cretácico inferior) de la Península Ibérica y Gondwana occidental: implicaciones paleobiogeográficas. In: PÉrez-Lorent F (Ed), Dinosaurios y otros reptiles mesozóicos de España. Ciencias de la Tierra 26: 251-268.

CARrano MT AND SAMPSON SD. 2002. Ceratosaurs: a global perspective. J Vertebr Paleontol 22 (Suppl 3): 41A.

CARRANO MT AND SAMPSON SD. 2008. The phylogeny of Ceratosauria (Dinosauria: Theropoda). J Syst Palaeontol 6: 183-236.

CARrano MT, SAMPSON SD AND Forster CA. 2002. The osteology of Masiakasaurus knopfleri, a small abelisauroid (Dinosauria: Theropoda) from the Late Cretaceous of Madagascar. J Vertebr Paleontol 22: 510-534.

Carvalho IS, Avilla LD and Salgado L. 2003. Amazonsaurus maranhensis gen. et sp. nov. (Sauropoda, Diplodocoidea) from the Lower Cretaceous (Aptian-Albian) of Brazil. Cretaceous Res 24: 697-713.

CARVAlHo IS AND Kattah S. 1998. As pegadas fósseis do paleodeserto da Bacia Sanfranciscana (Jurássico Superior-Cretáceo Inferior, Minas Gerais). An Acad Bras Cienc 70: 53-67.

Carvalho IS ANd Pedrão E. 2000. Brazilian theropods from the Equatorial Atlantic Margin: behavior and environmental setting. Gaia 15: 369-378.

CARVAlho IS, RiBeiro LCB AND AVILla LD. 2004. Uberabasuchus terrificus sp. nov., a new Crocodylomorpha from the Bauru Basin (Upper Cretaceous), Brazil. Gondwana Res 7: 975-1002.

CASAl G, CANDEIRo CRA, MARTINEZ R, IVANy E AND IBIRICU L. 2009. Theropod teeth (Dinosauria: Saurischia) from the Bajo Barreal Formation, Upper Cretaceous, Chubut Province, Argentina. Geobios 42: 553-560.

Casal G, Martinez R, Luna M, Sciutto JC And LAmanna M. 2007. Aeolosaurus colhuehuapensis sp. nov. (Sauropoda, Titanosauria), from the Bajo Barreal Formation, Upper Cretaceous of Argentina. Rev Bras Paleont 10: 53-62.

CASAMIQUela RM. 1967. Un nuevo dinosaurio ornitisquio Triasico (Pisanosaurus mertii; Ornithopoda) de la Formación Ischigualasto, Argentina. Ameghiniana 5: 47-64. 
Castro DF, Bertini RJ, SAntucci RM And Medeiros MA. 2007. Sauropods of the Itapecuru Group (Lower/ Middle Albian), São Luis-Grajaú Basin, Maranhão State, Brazil. Rev Bras Paleont 10: 195-200.

Charig AJ AND Milner AC. 1997. Baryonyx walkeri, a fish-eating dinosaur from the Wealden of Surrey. Bull Nat His Mus Geol 53: 11-70.

Chiappe LM, Norell MA AND Clark JM. 2002. The Cretaceous, short-armed Alvarezsauridae: Mononykus and its kin. In: CHIAPPE LM AND WITMER LM (Eds), Mesozoic birds: Above the heads of dinosaurs. Berkeley: University of California, p. 87-120.

CHIAPPE LM AND WALKER CA. 2002. Skeletal morphology and systematics of the Cretaceous Euenantiornithes (Ornithothoraces: Enantiornithes). In: CHIAPPE LM AND WiTMER LM (Eds), Mesozoic birds: Above the heads of dinosaurs. Berkeley: University of California, p. 240267.

Colbert EH. 1970. A saurischian dinosaur from the Triassic of Brazil. Am Mus Novit 2405: 1-39.

Colbert EH. 1989. The Triassic dinosaur Coelophysis. MNA Bull 57: 1-160.

CONEY PJ. 1982. Plate tectonic constraints on the biogeography of Middle America and the Caribbean region. Ann MO Bot Garden 69(3): 432-443.

Coria RA AND CAMbiaso AV. 2007. Ornithischia. In: Zulma G, Coria RA And SAlgado L (Eds), Patagonian Mesozoic reptiles (Life of the Past), Bloomington: Indiana University, p. 167-187.

Crompton AW And AtTridge J. 1986. Masticatory apparatus of the larger herbivores during Late Triassic and Early Jurassic times. In: PADIAN K (Ed), The beginning of the age of the dinosaurs: faunal change across the Triassic-Jurassic boundary, Cambridge: Cambridge University, p. 223-236.

Currie PJ, Vickers-Rich P AND Rich TH. 1996. Possible oviraptorosaur (Theropoda, Dinosauria) specimens from the Early Cretaceous Otway Group of Dinosaur Cove, Australia. Alcheringa 20: 73-79.

CURRY Rogers K. 2005. Titanosauria: a phylogenetic overview. In: CURry Rogers KA AND WiLson JA (Eds), The Sauropods: Evolution and Paleobiology. Berkeley: University of California, p. 50-103.

DA Rosa AAS, Leal LA, Boelter RA AND DAmbros CS. 2006. Um novo Sauropodomorpha para o Triássico Superior do sul do Brasil. In: SIMPÓSIO BRASILEIRO DE Paleontologia de Vertebrados, 5, Santa Maria, Revista Ciência e Natura, 31 p.
Dal Sasso C, Maganuco S, Buffetaut E and MenDEZ MA. 2005. New information on the skull of the enigmatic theropod Spinosaurus, with remarks on its size and affinities. J Vertebr Paleontol 25: 888-896.

Dias-Brito D, Musacchio EA, Castro JC, MaraNHÃO MSAS, SUAREZ JM AND RODRIGUES R. 2001. Grupo Bauru: uma unidade continental do Cretáceo no Brasil - concepções baseadas em dados micropaleontológicos, isotópicos e estratigráficos. Rev Paleobiol 20(1): 245-304.

DIEDRICH CG. 2009. Palaeogeographic evolution of the marine Middle Triassic marine Germanic Basin changements - with emphasis on the carbonate tidal flat and shallow marine habitats of reptiles in Central Pangaea. Global Planet Change 65: 22-55.

DZIK J. 2003. A beaked herbivorous archosaur with dinosaur affinities from the early Late Triassic of Poland. J Vertebr Paleontol 23: 556-574.

DZIK J AND Sulej T. 2007. A review of the early Late Triassic Krasiejow biota from Silesia, Poland. Palaeontol Pol 64: 3-27.

Elias FA, Bertini R and Medeiros MAA. 2007. Velociraptorinae (Maniraptoriformes) teeth from the Coringa flagstone outcrop, middle Cretaceous of the São Luís - Grajaú basin, Maranhão State, northern-northeastern Brazil. In: CARVALHo IS, CASSAB RCT, SCHWANKE C, Carvalho ma, Fernandes aCs, Rodrigues MAC, Carvalho MSS, ARAi M AND Oliveira MEQ (Eds), Paleontologia: Cenários de Vida. Rio de Janeiro, Interciência 1: 315-325.

Evans SE, Jones MEH And Krause DW. 2008. A giant frog with South American affinities from the Late Cretaceous of Madagascar. PNAS 105: 2951-2956.

EZCURRA MD. 2006. A review of the systematic position of the dinosauriform archosaur Eucoelophysis baldwini Sullivan \& Lucas, 1999 from the Upper Triassic of New Mexico, USA. Geodiversitas 28: 649-684.

EzCURRA MD. 2010. A new early dinosaur (Saurischia: Sauropodomorpha) from the Late Triassic of Argentina: a reassessment of dinosaur origin and phylogeny. J Syst Palaeont 8: 371-425.

EzCURRA M AND Novas FE. 2009. Guaibasauridae, a new clade of Triassic basal sauropodomorphs. J Vertebr Paleontol 29(Suppl 3): 92A.

Fara E, Saraiva AAF, Campos DA, Moreira JKR, Siebra DC AND Kellner AWA. 2005. Controlled excavations in the Romualdo Member of the Santana Formation (Early Cretaceous, Araripe Basin, northeastern 
Brazil): stratigraphic, palaeoenvironmental and palaeoecological implications. Palaeogeogr Palaeoclimatol Palaeoecol 218: 145-160.

Ferigolo J And Langer MC. 2007. A Late Triassic dinosauriform from south Brazil and the origin of the ornithischian predentary bone. Hist Biol 19: 23-33.

FERNANDES LA. 2004. Mapa litoestratigráfico da parte oriental da Bacia Bauru (PR, SP, MG), escala 1:1.000.000. Bol Paranaense Geoci 55: 53-66.

FERnANDES LA AND COIMBRA AM. 2000. Revisão estratigráfica da parte oriental da Bacia Bauru (Neocretáceo). Rev Bras Geoci 30: 717-728.

Fernandes MA And Carvalho IS. 2007. Pegadas fósseis da Formação Botucatu (Jurássico Superior-Cretáceo Inferior): o registro de um grande Dinossauro Ornithopoda na Bacia do Paraná. In: CARVALHO IS, CASSAB RCT, SCHWANKe C, CARVAlho MA, FernanDES ACS, Rodrigues MAC, CARVAlHo MSS, ARAi M AND Oliveira MEQ (Eds), Paleontologia: Cenários de Vida. Rio de Janeiro, Interciência 1: 417-424.

FERreira CS, AZEVEdo AS, CARVAlHo IS, GonçAlves RA AND VicAlvi MA. 1992. Os fósseis da Formação Itapecuru. In: SimPÓSIO SOBRE BACIAS CRETÁCICAS BRAsileiras, 2, Rio Claro, Resumos Expandidos... Rio Claro, UNESP, p. 107-110.

FORSTER CA. 1999. Gondwanan dinosaur evolution and biogeographic analysis. J Afr Earth Sci 28: 169-185.

FRANÇA MAG AND LANGER MC. 2006. Phylogenetic relationships of the Bauru Group turtles (Late Cretaceous of south-central Brazil). Rev Bras Paleont 9: 1-9.

Franco-Rosas AC. 2001. Dentes de teropodomorfos da Formação Cambambe, Mato Grosso. In: Congresso Brasileiro de Paleontologia, 17, Rio Branco, Boletim de Resumos, Rio Branco, UFAC, 157 p.

FRANCO-RosAS AC. 2002. Methodological parameters for identification and taxonomic classification of isolated theropodomorph teeth. An Acad Bras Cienc 74: 367.

Franco-Rosas AC, SAlgado L, Rosas CF AND CARVALHO IS. 2004. Nuevos materiales de titanosaurios (Sauropoda) em el Cretácico Superior de Mato Grosso, Brasil. Rev Bras Paleont 7: 329-336.

FRANKFURT NG AND ChIAPPE LM. 1999. A possible oviraptorosaur from the Late Cretaceous of northwestern Argentina. J Vertebr Paleontol 19: 101-105.

Freire PC, MEDEIRos MA AND Lindoso RM. 2007. Sauropod teeth diversity in the Laje do Coringa fossiliferous site, Eocenomanian of northeastern Brazil. In: Carvalho IS, CASSAB RCT, SchWanke C, CARva-
LHO MA, FERnANDES ACS, RODRIGUES MAC, CARVAlho MSS, ARAi M AND Oliveira MEQ (Eds), Paleontologia: Cenários de Vida. Rio de Janeiro, Interciência 1: 523-532.

Frey E AND MARTILl DM. 1995. A possible oviraptorosaurid theropod from the Santa Formation (Lower Cretaceous, ?Albian) of Brazil. N Jahrb Geol Paläont M 7: $397-412$.

Fuente M And BRoin FL. 1997. An Araripemys-like decorated pleurodire turtle in the Paleocene of northwestern Argentine. Geobios 30: 235-242.

Fulfaro VJ ANd Perinotto JAJ. 1996. A Bacia Bauru: Estado da Arte. In: Simpósio Sobre o CRETÁceo do Brasil, 4, Águas de São Pedro/Rio Claro, Boletim, Rio Claro, UNESP, p. 297-303.

Gaffney ES, Tong H And Meylan PA. 2006. Evolution of side-necked turtles: the families Bothermydidae, Euraxemydidade, and Araripemydidae. Bull Am Mus Nat Hist 300: 1-698.

Gallina PA AND Apesteguía S. 2005. Cathartesaura anaerobica gen. et sp. nov., a new rebbachisaurid (Dinosauria, Sauropoda) from the Huincul Formation (Upper Cretaceous), Rio negro, Argentina. Rev Mus Argentino Cienc Nat 7: $53-166$.

GaLton PM. 1977. Staurikosaurus pricei, an early saurischian dinosaur from The Triassic of Brazil, with notes on the Herrerasauridae and Poposauridae. Paläntol Z 51: 234-245.

Galton PM. 1985. The poposaurid thecodontian Teratosaurus suevicus v. Meyer, plus referred specimens mostly based on prosauropod dinosaurs, from the Middle Stubesandstein (Upper Triassic) of Nordwürttemberg. Stuttgarter Beiträge zur Naturkunde B 116: 1-29.

GALTON PM. 1990. Basal Sauropodomorpha-prosauropods. In: Weishampel DB, Dodson P And Osmólska H (Eds), The Dinosauria. Berkeley: University of California, p. 320-344.

Galton PM. 2000. Are Spondylosoma and Staurikosaurus (Santa Maria Formation, Middle-Upper Triassic, Brazil) the oldest saurischian dinosaurs? Paläeontol Z 74: $393-$ 423.

GALTON PM AND UPChURCH P. 2004a. Prosauropoda. In: Weishampel DB, Dodson P AND OSMOLSKA H (Eds), The Dinosauria, 2nd ed., Berkeley: University of California, p. 232-258.

Galton PM ANd Upchurch P. 2004b. Stegosauria. In: Weishampel DB, Dodson P AND Osmolska H (Eds), The Dinosauria, 2nd ed., Berkeley: University of California, p. 343-362. 
Galton PM and Van HeErden J. 1998. Anatomy of the prosauropod dinosaur Blikanasaurus cromptoni (Upper Triassic, South Africa), with notes on the other tetrapods from the lower Elliot Formation. Paläeontol Z 72: 163 177.

GASPARINI ZB. 1972. Los Sebecosuchia (Crocodilia) del territorio Argentino. Consideraciones sobre su 'status' taxonómico. Ameghiniana 9: 23-34.

Gasparini Z, Chiappe LM and Fernandez M. 1991. A new Senonian peirosaurid (Crocodylomorpha) from Argentina and a synopsis of the South American Cretaceous crocodilians. J Vertebr Paleontol 11: 316-333.

GAUTHIER J. 1986. Saurischian monophyly and the origin of birds. In: PADIAN K (Ed), The origin of birds and the evolution of flight. Mem Calif Acad Sci 8: 1-55.

Gibson SA, Thompson RN, Weska RK, Dickin AP AND LEONARDOS OH. 1997. Late Cretaceous rift-related upwelling and melting of the Trindade starting mantle plume head beneath western Brazil. Contrib Mineral Petrol 126: 303-314.

Gobbo-Rodrigues SR, Coimbra JC, Petri S ANd BerTINI RJ. 2003. Kwango Series (Congo), Bauru Group (Brasil) and Neuquén Basin (Argentina) ages, based on ostracodes and vertebrates. In: CONGRESSO BRASILEIRo De Paleontologia, 18, Brasília, Boletim de Resumos, Brasília, SBP, p. 152-153.

Gobbo-Rodrigues SR, Kellner AWA, Campos DA, Carvalho LB and Azevedo SAK. 2005. New information on theropod eggs from the Late Cretaceous Bauru Group, Brazil. Congresso Latino-americano de Paleontologia de Vertebrados, 2, Rio de Janeiro, Boletim de Resumos, Rio de Janeiro, Museu Nacional, 124 p.

Gobbo-Rodrigues SR, Petri S AND Bertini RJ. 1999. Ocorrências de Ostrácodes na Formação Adamantina do Grupo Bauru, Cretáceo Superior da Bacia do Paraná e possibilidades de correlação com depósitos isócronos argentinos. Parte I - Família Ilyocyprididae. Acta Geol Leopoldensia 23: 3-13.

Góes AM And Rossetti DF. 2001. Gênese da Bacia de São Luís-Grajaú, meio norte do Brasil. In: RossetTI DF, Góes AM and Truckenbrodt W (Eds), O Cretáceo na Bacia de São Luís-Grajaú. Belém, Museu Goeldi, p. 15-30.

Goldberg K And Garcia AJV. 2000. Palaeobiogeography of the Bauru Group, a dinosaur-bearing Cretaceous unit, northeastern Parana Basin, Brazil. Cretaceous Res 21: $241-254$.

GolonkA J AND Ford DW. 2000. Pangean (Late Carbo-
niferous-Middle Jurassic) paleoenvironment and lithofacies. Palaeogeogr Palaeoclimatol Palaeoecol 161: 1-34.

Gradstein F And OgG J. 2004. Geologic Time Scale 2004 - why, how, and where next! Lethaia 37: 175-181.

Haubold H ANd Klein H. 2002. Chirotherien und Grallatoriden aus der Unteren bis Oberen Trias Mitteleuropas und die Entstehung der Dinosauria. Hallesches Jahr Geowiss R B 24: 1-22.

HAY WW ET AL. 1999. An alternative global Cretaceous paleogeography. In: BERRERA E AND JOHNSON C (Eds), Evolution of Cretaceous Ocean/Climate Systems. Spec Pap Geol Soc Am 332: 1-48.

HeCKert AB AND LuCAS SG. 1998. Global correlation of the Triassic theropod record. Gaia 15: 63-74.

Holtz JR TR. 2004. Tyrannosauroidea. In: WeishamPEL DB, Dodson P AND OSMOLSKA H (Eds), The Dinosauria, 2nd ed., Berkeley: University of California, p. 111-136.

Holtz JR TR, Molnar RE And CurRie PJ. 2004. Basal Tetanurae. In: WeIshampel DB, Dodson P AND OsMOLSKA H (Eds), The Dinosauria, 2nd ed., Berkeley: University of California, p. 71-110.

Holz M And Scherer C. 2000. Sedimentological and paleontological evidence of paleoclimatic change during the South brazilian Triassic: the register of a global trend towards a humid paleoclimate. Zentralb Geol Paläont TI 11-12: 1589-1609.

HuENE F VON. 1942. Die fossilen Reptilien des südamerikanischen Gondwanalandes. Munich: C.H. Beck, 342 p.

Hwang SH, Norell MA, Ji Q and GaO K. 2004. A large compsognathid from the Early Cretaceous Yixian Formation of China. J Syst Palaeontol 2: 13-30.

IRMIS RB. 2005. The vertebrate fauna of the Upper Triassic Chinle Formation in northern Arizona. p. 63-88. In: Nesbitt SJ, PARKer WG AND IRMIS RB (Eds), Guidebook to the Triassic formations of the Colorado Plateau in northern Arizona: Geology, Paleontology, and History. Mesa Southwest Museum Bulletin 9: 63-88.

Irmis RB, Nesbitt SJ, PAdian K, Smith ND, TURner AH, Woody D And Downs A. 2007a. A Late Triassic dinosauromorph assemblage from New Mexico and the rise of dinosaurs. Science 317: 358-361.

Irmis RB, PARKER WG, Nesbitt SJ AND JUN L. 2007b. Early ornithischian dinosaurs: the Triassic record. Hist Biol 19: 3-22.

JANENSCH W. 1914. Übersicht über die Wirbeltierfauna der Tendaguru-Schichten, nebst einer kurzen Charakterisierung der neu aufgeführten Arten von Sauropoden. Archiv für Biontologie 3(1): 81-110. 
Kellner AWA. 1996a. Fossilized theropod soft tissue. Nature 379: 32-32.

KELLNER AWA. 1996b. Remarks on Brazilian dinosaurs. Mem Queensl Mus 39: 611-626.

KELLNER AWA. 1999. Short note on a new dinosaur (Theropoda, Coelurosauria) from the Santana formation (Romualdo Member, Albian), northeastern Brazil. Bol Mus Nac Geol 49: 1-8.

KELLNER AWA. 2001. New information on the theropod dinosaurs from the Santana Formation (Aptian-Albian), Araripe Basin, Northeastern Brazil. J Vertebr Paleont 21(Suppl 3): 67A.

Kellner AWA. 2002a. Membro Romualdo da Formação Santana, Chapada do Araripe, CE - um dos mais importantes depósitos fossilíferos do Cretáceo brasileiro. In: SchobBenhaus C, CAMpos DA, QueIroz ET, WinGE M AND BERBERT-Born MLC (Eds), Sítios Geológicos e Paleontológicos do Brasil. Brasília, DNPM/CPRM, p. 121-129.

Kellner AWA. 2002b. Review of Avian Mesozoic fossil feathers. In: CHIAPPE LM AND WitMER LM (Eds), Mesozoic Birds: above the Heads of Dinosaurs. Los Angeles: University of California, p. 389-404.

Kellner AWA ANd Azevedo SAK. 1999. A new sauropod dinosaur (Titanosauria) from the Late Cretaceous of Brazil. Nat Sci Mus Monogr 15: 111-142.

Kellner AWA, Azevedo SAK, Carvalho LB, HenRIQUes DDR, Costa T AND CAMpos DA. 2004. Bones ouf of the jungle: on a dinosaur locality from Mato Grosso, Brazil. J Vertebr Paleontol 24(Suppl 3): $78 \mathrm{a}$.

Kellner AWA, Azevedo SAK, Machado EB, CarVAlHo LB AND HENRIQUes DDR. 2011. A new dinosaur (Theropoda, Spinosauridae) from the Cretaceous (Cenomanian) Alcântara Formation, Cajual Island, Brazil. An Acad Bras Cienc 83: 99-108.

Kellner AWA And CAMpos DA. 1996. First Early Cretaceous theropod dinosaur from Brazil with comments on Spinosauridae. N Jahr Geol Paläeontol A 199: 151-166.

Kellner AWA AND CAMpos DA. 1999. Vertebrate Paleontology in Brazil: a review. Episodes 22: 238-251.

Kellner AWA And CAmpos DA. 2000. Brief review of dinosaur studies and perspectives in Brazil. An Acad Bras Cienc 72: 509-538.

Kellner AWA AND CAmpos DA. 2002. On a theropod dinosaur (Abelisauria) from the continental Cretaceous of Brazil. Arq Mus Nac 60: 163-170.
Kellner AWA, CAmpos DA, Azevedo SAK, Trotta MNF, Henriques DDR, CRAIK MMT AND SILVA HP. 2006. On a new titanosaur sauropod from the Bauru Group, Late Cretaceous of Brazil. Bol Mus Nac Geol 74: $1-31$.

Kellner AWA, CAmpos DA AND Trotta MNF. 2005. Description of a Titanosaurid Caudal series from the Bauru Group, Late Cretaceous of Brazil. Arq Mus Nac 63: 529-564.

Kellner AWA, Gallo V, SARaiva ASF, SAYão JM AND SILVA HP. 2002. On the fossil locality Ladeira do Berlenga (Santana Formation, Araripe Basin) in Piauí, Northeastern Brazil. Arq Mus Nac 60: 111-116.

Kellner AWA, Maisey JG And CAmpos DA. 1994. Fossil down feather from the lower Cretaceous of Brazil. Palaeontology 37: 489-492.

Kellner AWA, Pinheiro AEP, Azevedo SAK, HenRiQues DDR, CARVAlho LB AND Oliveira GR. 2009. A new crocodyliform from the Alcantara Formation (Cenomanian), Cajual Island, Brazil. Zootaxa 2030: $49-58$.

King MJ And Benton MJ. 1996. Dinosaurs in the Early and Mid Triassic? The footprint evidence from Britain. Palaeogeogr Palaeoclimatol Palaeoecol 122: 213-225.

Kischlat E-E. 1999. A new dinosaurian rescued from the Brazilian Triassic: Teyuwasu barberenai, new taxon. Paleontologia em Destaque 14(26): 58.

Kischlat E-E AND BarberenA MC. 1999. Triassic Brazilian dinosaurs: new data. Paleontologia em Destaque 14(26): 56.

Krause DW, O'CONNOR PM, Rogers KC, SAMPSON SD, BuCKLEy GA AND Rogers RR. 2006. Late Cretaceous terrestrial vertebrates from Madagascar: implications for Latin American biogeography. Ann Mo Bot Gard 93: 178-208.

Krause DW, SAMPSON SD, CARrano MT AND O'CONNOR PM. 2007. Overview of the history of discovery, taxonomy, phylogeny, and biogeography of Majungasaurus crenatissimus (Theropoda: Abelisauridae) from the Late Cretaceous of Madagascar. J Vertebr Paleontol (SVP Memoir 8) 27(Suppl 2): 1-20.

Kutty TS, Chatterjee S, Galton PM ANd UpChurch P. 2007. Basal sauropodomorphs (Dinosauria: Saurischia) from the Lower Jurassic of India: their anatomy and relationships. J Paleont 81: 1218-1240.

Lacerda Filho JV, Abreu Filho W, Valente CR, Oliveira CC And Albuquerque MC. 2004. Geo- 
logia e Recursos Minerais do Estado de Mato Grosso. Goiânia, CPRM/SICME, 200 p.

LANGER MC. 2003. The sacral and pelvic anatomy of the stem-sauropodomorph Saturnalia tupiniquim (Late Triassic, Brazil). Paleobios 23(2): 1-40.

LANGER MC. 2004. Basal saurischians. In: WEISHAMPEL DB, Dodson $P$ AND Osmolska H (Eds), The Dinosauria, 2nd ed., Berkeley: University of California, p. $25-46$.

LANGER MC. 2005a. Studies on continental Late Triassic tetrapod biochronology. II. The Ischigualastian and a Carnian global correlation. J S Am Earth Sci 19: 219-239.

LANGER MC. 2005b. Studies on continental Late Triassic tetrapod biochronology. I. The type locality of Saturnalia tupiniquim and the faunal succession in south Brazil. J S Am Earth Sci 19: 205-218.

LAnger MC, Abdala F, Richter M And Benton MJ. 1999. A sauropodomorph dinosaur from the Upper Triassic (Carnian) of southern Brazil. CR Acad Sci Sci Terre et Planèt 329: 511-517.

LANGER MC AND BENTON MJ. 2006. Early dinosaurs: a phylogenetic study. J Syst Palaeontol 4: 309-358.

LANGER MC, BitTENCOURT JS AND SCHUltz CL. $2007 \mathrm{~b}$. The inclusivity and phylogenetic position of Guaibasaurus candelariensis: a basal dinosaur from the Late Triassic of Brazil. J Vertebr Paleont 27(Suppl 3): 103A$104 \mathrm{~A}$.

LANGER MC, EZCURRA MD, BITTENCOURT JS AND NoVAS FE. 2010. The origin and early evolution of dinosaurs. Biol Rev 85: 55-110.

LANGER MC, FrANÇA MAG DE AND GABRIEL S. 2007c. The pectoral girdle and forelimb anatomy of the stemsauropodomorph Saturnalia tupiniquim (Late Triassic, Brasil). Spec Pap Palaeontol 77: 113-137.

LANGER MC, Ribeiro AM, Schultz CL AND FERIGOlO J. 2007a. The continental tetrapod-bearing Triassic of south Brazil. Bull NMMNHS 41: 201-218.

LAPPARENT AF. 1960. Les Dinosauriens du "Continental intercalaire" du Sahara central. Mem Soc Geol Fr Paleont 88A: 1-57.

Leal LA, Azevedo SAK, Kellner AWA AND DA RosA AAS. 2004. A new early dinosaur (Sauropodomorpha) from the Caturrita Formation (Late Triassic), Paraná Basin, Brazil. Zootaxa: 1-24.

Le Loeuff J And Buffetaut E. 1991. Tarascosaurus salluvicus, new genus, new species, a theropod dinosaur from the Upper Cretaceous of southern France. Geobios 24: 585-594.
LEONARDI G. 1980. On the discovery of an ichno-fauna (vertebrates and invertebrates) in the Botucatu Formation s.s. in Araraquara, São Paulo, Brazil. An Acad Bras Cienc 52: 559-567.

LEONARDI G. 1989. Inventory and statistics of the South American dinosaurian ichnofauna and its paleobiological interpretation. In: GILlETTE DD AND LOCKLEY MG (Eds), Dinosaur Tracks and Traces. Cambridge: Cambridge University, p. 165-178.

LEONARDi G. 1994. Annotated Atlas of South America Tetrapod Footprints (Devonian to Holocene) with an appendix on Mexico and Central America. Brasília, CPRM, $248 \mathrm{p}$.

LEONARdi G AND Borgomanero G. 1981. Sobre uma possível ocorrência de Ornithischia na formação Santana, Chapada do Araripe (Ceará). Rev Bras Geocienc 11: 1-4.

LEONARDI G AND CARVALHO IS. 2002. Jazigo Icnofossilífero do Ouro (Araraquara), SP - Ricas pistas de tetrápodes do Jurássico. In: SCHOBbenhaus C, CAMPos DA, Queiroz ET, Winge M AND BERBERT-BorN MLC (Eds), Sítios Geológicos e Paleontológicos do Brasil. Brasília, DNPM/CPRM, p. 39-48.

LEONARDi G AND CARvalho IS. 2007. Dinosaur ichnocoenosis from Sousa and Uiraúna-Brejo das Freiras basins, northeast Brazil. In: CARVALHO IS, CASSAB RCT, Schwanke C, Carvalho MA, Fernandes ACS, Rodrigues MAC, Carvalho MSS, Arai M AND Oliveira MEQ (Eds), Paleontologia: Cenários de Vida. Rio de Janeiro, Interciência 1: 355-369.

Leonardi G, Carvalho IS And FERnandes MA. 2007. The desert ichnofauna from Botucatu Formation (Upper Jurassic- Lower Cretaceous), Brazil. In: CARVALHO IS, Cassab RCT, Schwanke C, Carvalho MA, FerNANDES ACS, Rodrigues MAC, CARVAlho MSS, Arai M AND Oliveira MEQ (Eds), Paleontologia: Cenários de Vida. Rio de Janeiro, Interciência 1: 371383.

LEONARDI G AND Oliveira FH. 1990. A revision of the Triassic and Jurassic tetrapod footprints of Argentina and a new approach on the age and meaning of the Botucatu Formation footprints (Brazil). Rev Bras Geocienc 20: 216-229.

LiEBERMAN BS. 2002. Phylogenetic biogeography with and without the fossil record: gauging the effects of extinction and paleontological incompleteness. Palaeogeogr Palaeoclimatol Palaeoecol 178: 39-52.

LIEBERMAN BS. 2003. Paleobiogeography: the relevance of fossils to biogeography. Ann Rev Ecol Syst 34: 51-69. 
Lomolino MV, Riddle BR And Brown J. 2006. Biogeography, 3rd ed., Sunderlands: Sinauer, 691 p.

Lloyd GT, Davis Ke, Pisani D, TARver Je, Ruta M, SaKamoto M, Hone DWE, Jennings R And BenTON MJ. 2008. Dinosaurs and the Cretaceous Terrestrial Revolution. Proc R Soc London B 275: 2483-2490.

LONG RA AND MURRY PA. 1995. Late Triassic (Carnian and Norian) tetrapods from the Southwestern United States. Bull NMMNHS 4: 1-254.

LUCAS SG. 1998. Global Triassic tetrapod biostratigraphy and biochronology. Palaeogeogr Palaeoclimatol Palaeoecol 143: 345-382.

Lyrio MC, Bittencourt J, LeAl LA And Azevedo SAK. 2004. Saurischian remains from Caturrita Formation (Upper Triassic, Southern Brazil) and the Triassic dinosaur fauna from Brazil. In: SIMPÓSIO BRASILEIRO de Paleontologia de Vertebrados, 4, Rio Claro, Boletim de Resumos, Rio Claro, UNESP, p. 41-42.

Machado E, Azevedo S, Carvalho L, Henriques D AND Kellner A. 2009. A new spinosaurid from the Cretaceous Alcântara Formation (Maranhão), northeastern Brazil. J Vertebr Paleontol 29(Suppl 3): 138A.

Machado EB, Campos DA And Kellner AWA. 2008. On a theropod scapula (Upper Cretaceous) from the Marília Formation, Bauru Group, Brazil. Paläontol Z 82: 308-313.

Machado EB And Kellner AWA. 2005. Notas sobre Spinosauridae (Theropoda, Dinosauria). Anuário Inst Geocienc 28: 158-173.

Machado EB ANd Kellner AWA. 2007. On a supposed ornithischian dinosaur from the Santana Formation, Araripe Basin, Brazil. In: CARVALHO IS, CASSAB RCT, Schwanke C, Carvalho Ma, Fernandes ACS, Rodrigues MAC, CARVAlho MSS, ARAi M AND Oliveira MEQ (Eds), Paleontologia: Cenários de Vida. Rio de Janeiro, Interciência 1: 291-299.

MAHLER L. 2005. Record of abelisauridae (Dinosauria: Theropoda) from the Cenomanian of Morocco. J Vertebr Paleontol 25: 236-239.

MAISEY JG. 1990. Stratigraphy and depositional environment of the Crato Member (Santana Formation, Lower Cretaceous of N.E. Brazil). In: GRIMALDI D (Ed), Insects from the Santana Formation, Lower Cretaceous, of Brazil. Bull Am Mus Nat Hist 195: 15-19.

MAISEY JG. 1991. Santana fossils: an illustrated atlas. Neptune: T F H, 459 p.

MAISEY JG. 2000. Continental break up and the distribution of fishes in western Gondwana during the Early Cretaceous. Cretaceous Res 21: 281-314.

Makovicky PJ, Apesteguia $S$ And Agnolín FL. 2005. The earliest dromaeosaurid theropod from South America. Nature 437: 1007-1011.

MAKOVICKY PJ AND Norell MA. 2004. Troodontidae. In: Weishampel DB, Dodson P AND Osmolska H (Eds), The Dinosauria, 2nd ed., Berkeley: University of California, p. 184-195.

MAKOVICKY PJ AND SuEs H-D. 1998. Anatomy and phylogenetic relationships of the theropod dinosaur Microvenator celer from the Lower Cretaceous of Montana. Am Mus Novit 3240: 1-27.

MALKANi MS. 2006. Biodiversity of saurischian dinosaurs from the latest Cretaceous Park of Pakistan. J Appl Emerg Sci 1(3): 108-140.

MANNION PD. 2009. A rebbachisaurid sauropod from the Lower Cretaceous of the Isle of Wight, England. Cretaceous Res 30: 521-526.

MARINHO TS AND CANDEIRO CRA. 2005. Titanosaur (Dinosauria: Sauropoda) osteoderms from the Maastrichtian of Uberaba, Minas Gerais State, Brazil. Gondwana Res 8: $473-477$.

MARSH OC. 1869. Notice of some new reptilian remains from the Cretaceous of Brazil. Am J Sci 47: 390-392.

MARSICANO CA AND BARREDO SP. 2004. A Triassic tetrapod footprint assemblage from southern South America: palaeobiogeographical and evolutionary implications. Palaeogeogr Palaeoclimatol Palaeoecol 203: 313-335.

Marsicano CA, Domnanovich NS AND MANCUSO AC. 2007. Dinosaur origins: evidence from the footprint record. Hist Biol 19: 83-91.

Martill DM. 1993. Fossils of Santana and Crato Formations, Brazil. Palaent Assoc Field Guides to Fossils 5: $1-158$.

Martill DM. 2007a. The geology of the Crato Formation. In: MARTILl DM, Bechly G AND LOVERIDGE RF (Eds), The Crato fossil beds from Brazil: window into an ancient world. Cambridge: Cambridge University, p. 8-24.

MARTILL DM. 2007b. The age of the Cretaceous Santana Formation fossil Konservat Lagerstatten of north-east Brazil: a historical review and an appraisal of the biochronostratigraphic utility of its palaeobiota. Cretaceous Res 28: 895-920.

Martill DM AND BeChly G. 2007. Introduction to the Crato Formation. In: MARTILl DM, BECHLY G AND LOVERIDGE RF (Eds), The Crato fossil beds from Brazil: 
window into an ancient world. Cambridge: Cambridge University, p. 3-7.

Martill DM, Bechly G AND Loveridge RF (Eds). 2007a. The Crato fossil beds from Brazil: window into an ancient world. Cambridge University: Cambridge, 625 p.

Martill DM, Cruickshank ARI, Frey E, SMall PG AND ClARKE M. 1996. A new crested maniraptoran dinosaur from the Santana Formation (Lower Cretaceous) of Brazil. J Geol Soc 153: 5-8.

Martill DM ANd Figueira JBM. 1994. A new feather from the Lower Cretaceous of Brazil. Palaeontology 37: 483-487.

MARTILl DM AND FREY E. 1995. Colour patterning preserved in Lower Cretaceous birds and insects: the Crato Formation of N.E. Brazil. N Jahr Geol und Paläont M 2: 118-128.

Martill DM, Frey E, Sues HD ANd Cruickshank ARI. 2000. Skeletal remains of a small theropod dinosaur with associated soft structures from the Lower Cretaceous Santana Formation of northeastern Brazil. Can J Earth Sci 37: 891-900.

Martill DM and Heimhofer U. 2007. Stratigraphy of the Crato Formation. In: MARTILL DM, BECHLY G AND LOVERIDGE RF (Eds), The Crato fossil beds from Brazil: window into an ancient world. Cambridge: Cambridge University, p. 25-43.

MARTILl DM, LOVERIDGE R. AND HeIMHOFER U. 2007b. Halite pseudomorphs in the Crato Formation (Early Cretaceous, Late Aptian-Early Albian), Araripe Basin, northeast Brazil: further evidence for hypersalinity. Cretaceous Res 28: 613-620.

Martill DM AND Wilby PR. 1993. Stratigraphy. In: MARTILl DM (Ed), Fossils of the Santana and Crato Formations, Brazil. Palaeontol Assoc Field Guides to Fossils 5: 20-50.

Martinelli AG And Forasiepi AM. 2004. Late Cretaceous vertebrates from Bajo de Santa Rosa (Allen Formation), Rio Negro province, Argentina, with the description of a new sauropod dinosaur (Titanosauridae). Rev Mus Arg Ci Nat 6: 257-305.

MARTINEZ RN AND AlCOBER OA. 2009. A basal sauropodomorph (Dinosauria: Saurischia) from the Ischigualasto Formation (Triassic, Carnian) and the early evolution of Sauropodomorpha. PLoS ONE 4: 4391-4312.

Martins Neto RG And Kellner AWA. 1988. Primeiro registro de pena na Formação Santana (Crétaceo Inferior), Bacia do Araripe, Nordeste do Brasil. An Acad Bras Cienc 60: 61-68.
MAWSON J AND WoodwARD AS. 1907. On the Cretaceous Formation of Bahia (Brazil), and on the vertebrate fossils contained therein. Q J Geol Soc 63: 128-139.

MCCARTHY D. 2005. Biogeographical and geological evidence for a smaller, completely-enclosed Pacific Basin in the Late Cretaceous. J Biogeogr 32: 2161-2177.

Medeiros MA. 2006. Large theropod teeth from the Eocenomanian of northeastern Brazil and the occurence of Spinosauridae. Rev Bras Paleont 9: 333-338.

Medeiros MA, Freire PC, Pereira AA, Santos RAB, Lindoso RM, CoElho AFA, PAssos EB And SousA E. 2007. Another African dinosaur recorded in the Eocenomanian of Brazil and a revision on the paleofauna of the Laje do Coringa site. In: CARVALHO IS, CASSAB RCT, SchWANKe C, CARVAlHo MA, FERnANDes ACS, Rodrigues MAC, CARVAlho MSS, ARAi M AND Oliveira MEQ (Eds), Paleontologia: Cenários de Vida. Rio de Janeiro, Interciência 1: 413-423.

Medeiros MA AND Schultz CL. 2001. Uma paleocomunidade de vertebrados do Cretáceo médio, Bacia de São Luís. In: Rossetti DF, Góes AM AND TRUCKenBRODT W (Eds), O Cretáceo na Bacia de São Luís-Grajaú. Belém, Museu Goeldi, p. 209-221.

Medeiros MA AND Schultz CL. 2002. A fauna dinossauriana da "Laje do Coringa", Cretáceo Médio do nordeste do Brasil. Arq Mus Nac 60: 155-162.

Medeiros MA AND SCHUltz CL. 2004. Rayososaurus (Sauropoda, Diplodocoidea) no meso-Cretáceo do nortenordeste brasileiro. Rev Bras Paleont 7: 275-279.

Melchor RN ANd De VAlais S. 2006. A review of Triassic tetrapod track assemblages from Argentina. Palaeontology 49: 355-379.

MezzaliRA S. 1981. Léxico estratigráfico do estado de São Paulo. Bol Inst Geol 5: 1-161.

Milani EJ. 2001. Geodinâmica fanerozóica do Gondwana sul-ocidental e a evolução geológica da Bacia do Paraná. In: Ros LF AND Holz M (Orgs), Geologia do Rio Grande do Sul. Porto Alegre, UFRGS, p. 275-302.

Milani EJ. 2004. Comentários sobre a origem e evolução tectônica da Bacia do Paraná. In: Mantesso Neto V, Bartorelli A, CARneiro CDR ANd BRito NeVES BB (Orgs), Geologia do continente sul-americano: evolução da obra de Fernando Flávio Marques de Almeida. São Paulo, Beca, p. 265-279.

Mohriak WU. 2003. Bacias Sedimentares da Margem Continental Brasileira. In: BIZZI LA, SCHOBBENHAUS C, Vidotti RM And Gonçalves JH (Eds), Geologia, Tectônica e Recursos Minerais do Brasil. Brasília, CPRM, p. 87-94. 
Montellano-Ballesteros M. 2003. A titanosaurid sauropod from the Upper Cretaceous of Chihuahua, Mexico. Rev Mexic Cienc Geol 20: 160-164.

Moreno K AND Benton MJ. 2005. Occurrence of sauropod dinosaur tracks in the Upper Jurassic of Chile (redescription of Iguanodonichnus frenki). J S Am Earth Sci 20: 253-257.

Morrone JJ And Guerrero JC. 2008. General trends in world biogeographic literature: A preliminary bibliometric analysis. Rev Bras Entomol 52: 493-499.

NAish D, MARTILl DM AND Frey E. 2004. Ecology, systematics and biogeographical relationships of dinosaurs, including a new theropod, from the Santana Formation (?Albian, Early Cretaceous) of Brazil. Hist Biol 16: 57-70.

Naish D, Martill DM And Merrick I. 2007. Birds of the Crato Formation. In: MARTILl DM, BeChLy G AND Loveridge RF (Eds), The Crato fossil beds from Brazil: window into an ancient world. Cambridge: Cambridge University, p. 525-533.

Nesbitt SJ And ChatterjeE S. 2008. Late Triassic dinosauriforms from the Post Quarry and surrounding areas, west Texas, USA. N Jahr Geol Paläont A 249: 143-156.

Nesbitt SJ, IRmis RB AND PARKer WG. 2007. A critical re-evaluation of the Late Triassic dinosaur taxa of North America. J Syst Palaeontol 5: 209-243.

Nesbitt SJ, Sidor CA, Irmis RB, AngielczyK KD, SMith RMH AND Tsuji LA. 2010. Ecologically distinct dinosaurian sister group shows early diversification of Ornithodira. Nature 464: 94-98.

Nesbitt SJ, Smith ND, IRmis RB, TuRner AH, Downs A AND Norell MA. 2009. A complete skeleton of a Late Triassic saurischian and the early evolution of dinosaurs. Science 326: 1530-1533.

Neumann VH And CABrera L. 1999. Una nueva propuesta estratigráfica para la tectonosecuencia post-rifte de la Cuenca de Araripe, nordeste de Brasil. In: SIMPÓsIO SOBRE O CRETÁCEO DO BRASIL, 5, Serra Negra, Boletim... Rio Claro, Unesp, p. 279-285.

Neumann VH, Cabrera L, Mabesoone JM, Valença LMM AND SILVA AL. 2002. Ambiente sedimentar e fácies da sequência lacustre aptiana-albiana da Bacia do Araripe, NE do Brasil. In: SIMPÓsIo de BACIA CRETÁCICAs Sul-Americanas, 6, São Pedro, Boletim... Rio Claro, UNESP, p. 37-41.

Niedzwiedzki G, Piechowski R And Sulej T. 2009. New data on the anatomy and phylogenetic position of Silesaurus opolensis from the late Carnian of Poland. J Vertebr Paleontol 29(Suppl 3): 155A.
NobRE PH. 2004. Morfologia pós-craniana de Candidodon itapecuruense (Crocodylomorpha, Mesoeucrocodylia), do Cretáceo do Brasil. Rev Bras Paleont 7: 87-92.

Norell MA AND Makovicky PJ. 2004. Dromaeosauridae. In: WeISHAMPEL DB, Dodson P AND OSMOLSKA H (Eds), The Dinosauria, 2nd ed., Berkeley: University of California, p. 196-209.

NORMAN DB. 2004. Basal Iguanodontia. In: WeIsHAMPEL DB, DODSON P AND OSMOLSKA H (Eds), The Dinosauria, 2nd ed., Berkeley: University of California, p. $413-437$.

Norman DB, Sues H-D, Witmer LM, Coria RA. 2004. Basal Ornithopoda. In: WeISHAMPEL DB, DODSON P AND Osmolska H (Eds), The Dinosauria, 2nd ed., Berkeley: University of California, p. 393-412.

Novas FE. 1997. Herrerasauridae. In: CURRIE PJ AND PADIAN K (Eds), Encyclopedia of Dinosaurs. San Diego: Academic Press, p. 303-311.

Novas FE. 2007. Evolution of South American dinosaurs. In: CARVAlHo IS, CASSAB RCT, SCHWANKE C, CARVAlho MA, Fernandes ACS, Rodrigues MAC, CARVAlho MSS, ARAi M AND Oliveira MEQ (Eds), Paleontologia: Cenários de Vida. Rio de Janeiro, Interciência 1: 333-353.

Novas FE. 2009. The Age of Dinosaurs in South America. Bloomington: Indiana University Press, $452 \mathrm{p}$.

Novas FE, CARvalho ID, Ribeiro LCB AND Mendez AH. 2008. First abelisaurid bone remains from the Maastrichtian Marília Formation, Bauru Basin, Brazil. Cretaceous Res 29: 625-635.

Novas FE, Chatterjee S, Ezcurra M And Kutty T. 2009a. New dinosaur remains from the Late Triassic of central India. J Vertebr Paleont 29(Suppl 3): 156A.

Novas FE, Dalla Vecchia F AND PAis DF. 2006. Theropod pedal unguals from the Late Cretaceous (Cenomanian) of Morocco, Africa. Rev Mus Argentino Cienc Nat 7: 167-175.

Novas FE, De Valais S, Vickers-Rich P AND Rich T. 2005a. A large Cretaceous theropod from Patagonia, Argentina, and the evolution of carcharodontosaurids. Naturwissenschaften 92: 226-230.

Novas FE AND Pol D. 2005. New evidence on deinonychosaurian dinosaurs from the Late Cretaceous of Patagonia. Nature 433: 858-861.

Novas FE, Pol D, Canale Ji, Porfiri JD and Calvo JO. 2009b. A bizarre Cretaceous theropod dinosaur from Patagonia and the evolution of Gondwanan dromaeosaurids. Proc R Soc London B 276: 1101-1107. 
Novas FE AND PUERTA PF. 1997. New evidence concerning avian origins from the Late Cretaceous of Patagonia. Nature 387: 390-392.

Novas FE, Ribeiro LCB AND CARvalho IS. 2005b. Maniraptoran theropod ungual from the Marilia Formation (Upper Cretaceous), Brazil. Rev Mus Arg Ci Nat 7: 31-36.

PADIAN K. 2004. Basal Avialae. In: Weishampel DB, Dodson P AND Osmolska H (Eds), The Dinosauria, 2nd ed., Berkeley: University of California, p. 210-231.

PADIAN K AND CHIAPPE LM. 1998. The origin and early evolution of birds. Biol Rev 73: 1-42.

Padian K, Hutchinson JR and Holtz TR. 1999. Phylogenetic definitions and nomenclature of the major taxonomic categories of the carnivorous Dinosauria (Theropoda). J Vertbr Paleontol 19: 69-80.

PADIAN K AND MAY CL. 1993. The earliest dinosaurs. Bull NMMNHS 3: 379-381.

PARker WG, Irmis RB, Nesbitt SJ, Martz JW AND Browne LS. 2005. The Late Triassic pseudosuchian Revueltosaurus callenderi and its implications for the diversity of early ornithischian dinosaurs. Proc R Soc London B 272: 963-969.

Pereda-Suberbiola X. 2009. Biogeographical affinities of Late Cretaceous continental tetrapods of Europe: a review. Bull Soc Geolog France 180: 57-71.

PETRI S. 1987. Cretaceous paleogeographic maps of Brazil. Palaeogeogr Palaeoclimatol Palaecol 59: 117-168.

Pons D, BERTHOU PY AND CAMPOS DA. 1990. Quelques observations sur la palynologie de l'Aptien Supérieur el de l'Albien du bassin d'Araripe (N.E. du Brésil). In: SIMPÓSIO SOBRE A BACIA DO ARARIPE E BACIAS INTERIORES Do Nordeste, Crato, Atas, Crato, URCA, p. 241-252.

Ponte FC. 1996. Arcabouço estrutural da Bacia do Araripe. In: Simpósio Sobre o CRetáceo do Brasil, 4, Águas de São Pedro/Rio Claro, Boletim, Rio Claro, UNESP, p. 169-177.

PONTE FC AND APPI CJ. 1990. Proposta de revisão da coluna litoestratigráfica da Bacia do Araripe. In: CONGresso Brasileiro De Geologia, 36, Natal, Anais, Natal, SBP, p. 211-226.

Ponte FC And Ponte Filho FC. 1996. Evolução tectônica e classificação da Bacia do Araripe. In: SiMPÓsio SOBRE o Cretáceo do Brasil, 4, Águas de São Pedro/Rio Claro, Boletim, Rio Claro, UNESP, p. 123-133.

Porfiri JD, Calvo JO, VAlieri RJ AND SANTOS D. 2008. A large theropod from Bajo de La Carpa Forma- tion (Late Cretaceous) of Neuquén, Patagonia. In: CONGReso LatinoAmericano DE PALEOntología DE Vertebrados, 3, Neuquén, Libro de Resúmenes, Neuquén, UNC, p. 202.

Powell JE. 2003. Revision of South American titanosaurid dinosaurs: palaeobiological, palaeobiogeographical and phylogenetic aspects. Rec Queen Victoria Mus 111: 1-173.

PRICE LI. 1960. Dentes de Theropoda num testemunho de sonda no estado do Amazonas. An Acad Bras Cienc 32: 79-84.

PRICE LI. 1961. Sobre os dinossáurios do Brasil. An Acad Bras Cienc 33(3-4): xxviii-xxix.

RAATH MA. 1996. Earliest evidence of dinosaurs from central Gondwana. Mem Queensl Mus 39: 703-709.

RAuHut OWM. 1995. Zur systematischen Stellung der afrikanischen Theropoden Carcharodontosaurus Stromer 1931 und Bahariasaurus Stromer 1934. Berl Geowiss A R Palaeobiol 16: 357-375.

RAUHUT OWM. 2003. The interrelationships and evolution of basal theropod dinosaurs. Spec Pap Palaeontol 69: 1213.

RAUHUT OWM. 2005. Post-cranial remains of 'coelurosaurs' (Dinosauria, Theropoda) from the Late Jurassic of Tanzania. Geol Magazine 142: 97-107.

RAuHut OWM AND HungERBÜHLER A. 1998. A review of European Triassic theropods. Gaia 15: 75-88.

RAuHuT OWM AND LOPEZ-ARBARELlo A. 2008. Archosaur evolution during the Jurassic: a southern perspective. Rev Asoc Geol Argentina 63: 557-585.

Rauhut OWM, Remes K, Fechner R, CALdera G AND PUERTA P. 2005. Discovery of a short-necked sauropod dinosaur from the Late Jurassic period of Patagonia. Nature 435: 670-672.

RAUHUT OWM AND WERNER C. 1995. First record of the family Dromaeosauridae (Dinosauria: Theropoda) in the Cretaceous of Gondwana (Wadi Milk Formation, northern Sudan). Paläeontol Z 69: 475-489.

RAY S AND CHINSAMY A. 2002. A theropod tooth from the Late Triassic of southern Africa. J Biosci 27: 295-298.

ReE RH AND SMith SA. 2008. Maximum likelihood inference of geographic range evolution by dispersal, local extinction, and cladogensis. Syst Biol 57: 4-14.

REMES K. 2006. Revision of the Tendaguru sauropod dinosaur Tornieria africana (Fraas) and its relevance for sauropod paleobiogeography. J Vertebr Paleontol 26: 651-669. 
REMES K. 2007. A second gondwanan diplodocid dinosaur from the Upper Jurassic Tendaguru Beds of Tanzania, East Africa. Palaeontology 50: 653-667.

Ribeiro CMM. 1999. Ovos fósseis da Formação Marília (Bacia Bauru, Cretáceo Superior). An Acad Bras Cienc 71: 850 .

Ribeiro LL, Moraes-SAntos HM ANd Medeiros MA. 2003. Ocorrência de Theropoda na localidade Coroatá, cento-leste Maranhão. Paleontologia em Destaque 44: 50.

RifF D AND Kellner AWA. 2001. On the dentition of Baurusuchus pachecoi Price (Crocodyliformes, Metasuchia) from the Upper Cretaceous of Brazil. Bol Mus Nac Geol 59: 1-15.

Rogers RR, Swisher CC, Sereno PC, Monetta AM, Forster CA AND MARTinez RN. 1993. The Ischigualasto tetrapod assemblage (Late Triassic, Argentina) and $\mathrm{Ar}^{40} / \mathrm{Ar}^{39}$ dating of dinosaur origins. Science 260 : 794-797.

RoNQUIST F. 1997. Dispersal-vicariance analysis: A new approach to the quantification of historical biogeography. Syst Biol 46: 195-203.

RosA DB, WeskA RK AND Lima PRM. 1991. Formas de sílicas fibrosas associadas a evaporitos em rochas pertencentes à Fácies Cambambe (Grupo Bauru), na região de Água Fria, Chapada dos Guimarães, MT. In: SIMPÓsıo de Geologia do Centro-Oeste, 3, Cuiabá, Anais, Cuiabá, SBG, p. 211.

Rossetti DF. 2001. Arquitetura deposicional da Bacia de São Luís-Grajaú. In: Rossetti DF, GóEs AM AND Truckenbrodt W (Eds), O Cretáceo na Bacia de São Luís-Grajaú. Belém, Museu Goeldi, p. 31-46.

Rossetti DF, Góes AM AND ARAi M. 2001a. A passagem Aptiano-Albiano na Bacia do Grajaú, MA. In: RossetTI DF, Góes AM AND TRUCKENBROdT W (Eds), O Cretáceo na Bacia de São Luís-Grajaú. Belém, Museu Goeldi, p. 101-117.

Rossetti DF And TRUCKEnBrodT W. 1997. Classificação estratigráfica para o Albiano-Terciário Inferior (?) na Bacia de São Luís, MA. Bol Mus Para Emílio Goeldi 9: $31-43$.

Rossetti DF, TRUCKEnBRodt W AND SANTOS JÚNior AE. 2001b. Clima do Cretáceo no Meio-norte brasileiro. In: Rossetti DF, Góes AM AND TRUCKenbrodT W (Eds), O Cretáceo na Bacia de São Luís-Grajaú. Belém, Museu Goeldi, p. 67-76.

RUBERT RR AND SCHULTZ CL. 2004. Um novo horizonte de correlação para o Triássico Superior do Rio Grande do Sul. Pesq Geoci 31(1): 71-88.
RUSSELL DA. 1996. Isolated dinosaur bones from the Middle Cretaceous of the Tafilalt, Morocco. Bull Mus Nat d'Hist Nat C 18: 349-402.

SAlgado L AND CARVAlHo IS. 2008. Uberabatitan ribeiroi, a new titanosaur from the Marília Formation (Bauru Group, Upper Cretaceous), Minas Gerais, Brazil. Palaeontology 51: 881-901.

Salgado L, Coria RA AND CAlvo JO. 1997. Evolution of titanosaurid sauropods. I. Phylogenetic analysis based on the postcranial evidence. Ameghiniana 34: 3-32.

SAlgado L, Garrido A, Cocca SE AND CoccA JR. 2004. Lower Cretaceous Rebbachisaurid sauropods from Cerro Aguada del Leon (Lohan Cura Formation), Neuquén Province, Northwestern Patagonia, Argentina. J Vertebr Paleontol 24: 903-912.

SAMpson SD, WitMER LM, Forster CA, KraUse DW, O'Connor PM, Dodson P AND RAVOAVY F. 1998. Predatory dinosaur remains from Madagascar: Implications for the Cretaceous biogeography of Gondwana. Science 280: 1048-1051.

SAntos MECM ANd CARvalho MSS. 2004. Paleontologia das Bacias do Parnaíba, Grajaú e São Luiz: reconstituições paleobiológicas. Rio de Janeiro, CPRM, 211 p.

SAntuCCi RM AND Bertini RJ. 2001. Paleogeographical and biochronological distributions of the Bauru Group titanosaurids (Saurischia, Sauropoda) Upper Cretaceous of southeastern Brazil. Rev Bras Geoci 31: 307-314.

SANTUCCI RM AND BERTINI RJ. 2006a. A large sauropod titanosaur from Peirópolis, Bauru Group, Brazil. N Jahr Geol Paläont M 6: 344-360.

SAntuCCi RM AND Bertini RJ. 2006b. A new titanosaur from western São Paulo State, Upper Cretaceous Bauru Group, South-East Brazil. Palaeontology 49: 59-66.

SCALERA G. 2001. The global paleogeographical reconstruction of the Triassic in the Earth's dilatation framework and the paleoposition of India. Ann Geofis 44: 13-32.

SCHERER CMS. 2000. Eolian dunes of the Botucatu Formation (Cretaceous) in Southernmost Brazil: morphology and origin. Sediment Geol 137: 63-84.

SCHERER CMS, FACCINI UF, BARBERENA MC, SCHUltz CL AND LAVINA EL. 1995. Biostratigrafia da Formação Santa Maria: utilização das cenozonas como horizontes de correlação. Comun Mus Ci Tecno PUCRS Ci Terra 1: 43-50.

SCHERER CMS, FACCINI UF AND LAVINA EL. 2000. Arcabouço Estratigráfico do Mesozóico da Bacia do Paraná. In: Ros LF AND Holz M (Orgs), Geologia do Rio Grande do Sul. Porto Alegre, UFRGS, p. 335-354. 
SCOTESE CR. 2002. Paleomap Project. $<\mathrm{http}: / /$ www.scotese.com $>$

SENTER P. 2007. A new look at the phylogeny of Coelurosauria (Dinosauria: Theropoda). J Syst Palaeontol 5: $429-463$.

SERENO PC. 1999a. Dinosaurian biogeography: vicariance, dispersal and regional extinction. Nat Sci Mus Monogr 15: 249-257.

SERENO PC. 1999b. The evolution of dinosaurs. Science 284: 2137-2147.

Sereno PC And ArCuCCI AB. 1994. Dinosaurian precursors from the Middle Triassic of Argentina: Marasuchus lilloensis, gen. nov. J Vertebr Paleontol 14: 53-73.

SERENO PC ET AL. 1998. A long-snouted predatory dinosaur from Africa and the evolution of spinosaurids. Science 282: 1298-1302.

SERENO PC ET AL. 1999. Cretaceous sauropods from the Sahara and the uneven rate of skeletal evolution among dinosaurs. Science 286: 1342-1347.

Sereno PC And Brusatte SL. 2008. Basal abelisaurid and carcharodontosaurid theropods from the lower Cretaceous Elrhaz Formation of Niger. Acta Palaeontol Pol 53: $15-46$.

Sereno PC, Dutheil DB, IARochene M, LARSSon HCE, LYON GH, MAGWENE PM, SIDOR CA, VARRICCHIO DJ AND WILsON JA. 1996. Predatory dinosaurs from the Sahara and Late Cretaceous faunal differentiation. Science 272: 986-991.

Sereno PC And Larsson HCE. 2009. Cretaceous crocodyliforms from the Sahara. ZooKeys 28: 1-143.

Sereno PC, Larsson HCE, Sidor CA And GAdo B. 2001. The giant crocodyliform Sarcosuchus from the Cretaceous of Africa. Science 294: 1516-1519.

Sereno PC, MCAllister S And Brusatte SL. 2005. TaxonSearch: a relational database for suprageneric taxa and phylogenetic definitions. PhyloInformatics 8: 1-21.

SERENO PC AND Novas FE. 1992. The complete skull and skeleton of an early dinosaur. Science 258: 1137-1140.

Sereno PC, Sidor CA, Larsson HCE AND Gado B. 2003. A new notosuchian from the Early Cretaceous of Niger. J Vertebr Paleontol 23: 477-482.

SERENO PC AND Wilson JA. 2005. Structure and evolution of a sauropod tooth battery. In: CURRY ROGERS KA AND Wilson JA (Eds), The Sauropods, Evolution and Paleobiology. Berkeley: University of California, p. $157-177$.

SERENo PC, Wilson JA AND CONRAD JL. 2004. New di- nosaurs link southern landmasses in the Mid-Cretaceous. Proc R Soc London B 271: 1325-1330.

Sereno PC, Wilson JA, Witmer LM, Whitlock JA, MagA A, Ide O AND Rowe TA. 2007. Structural extremes in a Cretaceous dinosaur. PLoS ONE 2: e1230, 1231-1239.

SILL WD. 1969. The tetrapod-bearing continental triassic sediments of south America. Am J Sci 267: 805-821.

Silva AJP, Lopes RCL, VAsconcelos AM AND BAHIA RBC. 2003. Bacias Sedimentares Paleozóicas e MesoCenozóicas Interiores. In: BIzzI LA, SchobBenHAus C, Vidotti RM And Gonçalves JH (Eds), Geologia, Tectônica e Recursos Minerais do Brasil. Brasília, CPRM, p. 55-85.

Silva AL, Neumann VH And Cabrera L. 2002. Fácies carbonáticas laminadas da Formação Crato (Aptiano), Bacia do Araripe: litofácies, microfáceis e microestruturas. In: Simpósio Sobre o CretÁceO do Brasil, 6, São Pedro, Boletim, Rio Claro, UNESP, p. 31-36.

Silva HP AND Kellner AWA. 1999. Novos dentes de theropoda do Cretáceo continental do Brasil. Paleontologia em Destaque 26: 66.

Silva RC, Carvalho ID ANd Fernandes ACS. 2008. Dinosaur footprints from the Triassic (Santa Maria Formation) of Brazil. Ameghiniana 45: 783-790.

SIMPSON GG. 1950. History of the Fauna of Latin America. Am Sci 38: 361-389.

SIMPSON GG. 1978. Early mammals in South America: fact, controversy and mystery. Proc Am Phil Soc 122: 318328.

SHUBIN NH AND SuES H-D. 1991. Biogeography of Early Mesozoic continental tetrapods: patterns and implications. Paleobiology 17: 214-230.

Smith JB and Dalla Vecchia FM. 2006. An abelisaurid (Dinosauria: Theropoda) tooth from the Lower Cretaceous Chicla Formation of Libya. J Afr Earth Sci 46: 240-244.

Smith JB AND LAmanna MC. 2006. An abelisaurid from the Late Cretaceous of Egypt: implications for theropod biogeography. Naturwissenschaften 93: 242-245.

SMith JB, LAMANNA MC, MAYR H AND LACOVARA KJ. 2006. New information regarding the holotype of Spinosaurus aegyptiacus Stromer, 1915. J Paleontol 80: 400406.

Smith ND, Makovicky PJ, Agnolin FL, Ezcurra MD, Pais DF And SAlisbury SW. 2008. A Megaraptor-like theropod (Dinosauria : Tetanurae) in Australia: support for faunal exchange across eastern and western 
Gondwana in the mid-Cretaceous. Proc R Soc London B 275: 2085-2093.

Smith AG, Smith DG And Funnell BM. 1994. Atlas of Mesozoic and Cenozoic Coastlines. Cambridge: Cambridge University, $99 \mathrm{p}$.

SoARes PC, LANDim PMB, Fulfaro VJ AND Sobreiro Neto AF. 1980. Ensaio de caracterização estratigráfica do Cretáceo no estado de São Paulo: Grupo Bauru. Rev Bras Geocienc 10: 177-185.

STROMER E. 1915. Ergebnisse der Forscungsreisen Prof. E. Stromers in den Wüsten Agyptens, II. Wirbeltiere-Reste der Baharije-Stufe (unterstes Cenoman) 3. Das Original des Theropoden Spinosaurus aegyptiacus nov. gen., nov. spec. Abh Königl Bayerisch Akad Wissensch 28(3): 132.

Stromer E. 1934. Ergebnisse der Forscungsreisen Prof. E. Stromers in den Wusten Agyptens, II. Wirbeltiere-Reste der Baharije-Stufe (unterstes Cenoman) 13. Dinosauria. Abh Königl Bayerisch Akad Wissensch 22: 1-79.

Sues HD, Frey E, MARTILl DM AND ScotT DM. 2002. Irritator challengeri, a spinosaurid (Dinosauria: Theropoda) from the Lower Cretaceous of Brazil. J Vertebr Paleontol 22: 535-547.

SUlLivan RM AND LUCAS SG. 2000. Alamosaurus (Dinosauria: Sauropoda) from the late Campanian of New Mexico and its significance. J Vertebr Paleontol 20: 400403.

TAquet P AND Russell DA. 1998. New data on spinosaurid dinosaurs from the Early Cretaceous of the Sahara. C R Acad Sci Sci Terre Planet 327: 347-353.

TAYLOR MP AND NAISH D. 2007. An unusual new neosauropod dinosaur from the lower cretaceous hastings beds group of East Sussex, England. Palaeontology 50: 15471564.

Trotta MNF, Campos DA AND Kellner AWA. 2002. Unusual caudal vertebral centra of a titanosaurid (Dinosauria, Sauropoda) from the continental Upper Cretaceous of Brazil. Bol Mus Nac Geol 64: 1-12.

TuCKer ME AND Benton MJ. 1982. Triassic environments, climates and reptiles evolution. Palaeogeogr Palaeoclimatol Palaeoecol 40: 361-369.

TURNER AH. 2004. Crocodyliform biogeography during the Cretaceous: evidence of Gondwanan vicariance from biogeographical analysis. Proc R Soc London B 271: 2003-2009.

TURNER AH. 2006. Osteology and phylogeny of a new species of Araripesuchus (Crocodyliformes : Mesoeucro- codylia) from the Late Cretaceous of Madagascar. Hist Biol 18: 255-369.

TuRner AH And CALvo JO. 2005. A new sebecosuchian crocodyliform from the Late Cretaceous of Patagonia. J Vertebr Paleont 25: 87-98.

TYKOSKI RS AND Rowe T. 2004. Ceratosauria. In: WEISHAMPEL DB, Dodson P AND OSMOLSKA H (Eds), The Dinosauria, 2nd ed., Berkeley: University of California, p. 47-70.

UPCHURCH P. 1995. The evolutionary history of sauropod dinosaurs. Phil Trans R Soc B 349: 365-390.

UPCHURCH P. 1999. The phylogenetic relationships of the Nemegtosauridae (Saurischia, Sauropoda). J Vertebr Paleont 19: 106-125.

UpChURCh P AND BARReTt PM. 2005. Phylogenetic and taxic perspectives on sauropod diversity. In: CURRY Rogers KA AND WiLson JA (Eds), The Sauropods: Evolution and Paleobiology. Berkeley: University of California, p. 104-124.

UPChURCh P, BARRETT PM AND DodSON P. 2004. Sauropoda. In: WeISHAMPEL DB, DODSON P AND OsMOLSKA H (Eds), The Dinosauria, 2nd ed., Berkeley: University of California, p. 259-322.

Upchurch P, Hunn CA ANd Norman DB. 2002. An analysis of dinosaurian biogeography: evidence for the existence of vicariance and dispersal patterns caused by geological events. Proc R Soc London B 269: 613-621.

VAN TOMme MPA, MedeIRos MAA ANd Machado EB. 2008. On an enigmatic theropod tibia from the Alcântara Formation (Late Cretaceous, early Cenomanian) of Maranhão, NE Brazil. In: SIMPÓsio BRASILEIRO DE Paleontologia de Vertebrados, 6, Ribeirão Preto, Boletim de Resumos, Ribeirão Preto, SBP, Paleontologia em Destaque, p. 199-200.

Viana MS AND NeUmann VHL. 2002. Membro Crato da Formação Santana, Chapada do Araripe, CE - Riquíssimo registro de fauna e flora do Cretáceo In: SCHOBBENhaus C, CAmpos DA, QueIRoz ET, Winge M AND Berbert-Born MLC (Eds), Sítios Geológicos e Paleontológicos do Brasil. Brasília, DNPM/CPRM, p. 113120.

Vilas Bôas I, CARvalho IS, Medeiros MA And PonTES H. 1999. Dentes de Carcharodontosaurus (Dinosauria, Tyranosauridae [sic]) do Cenomaniano, Bacia de São Luís (norte do Brasil). An Acad Bras Cienc 71: 846-847.

Weishampel DB, BARRETT PM, CORIA RA, LE LOEUfF J, Xu X, Zhao X, SAhni A, Gomani EMP AND Noto 
CR. 2004. Dinosaur distribution. In: WeISHAMPEL DB, Dodson P AND Osmolska H (Eds), The Dinosauria, 2nd ed., Berkeley: University of California, p. 517-606.

WESKA RK. 2006. Uma síntese do Cretáceo Superior matogrossense. Geociências 25: 71-81.

Weska RK, SVISERo DP AND LeONARdos HO. 1996. Contribuição ao conhecimento do Grupo Bauru no Estado de Mato Grosso, Brasil. In: Simpósio sobre o Cretáceo do Brasil, 4, Águas de São Pedro/Rio Claro, Boletim, Rio Claro, UNESP, p. 289-295.

WILSON JA. 2002. Sauropod dinosaur phylogeny: critique and cladistic analysis. Zoo J Linn Soc 136: 217-276.

WILSON JA. 2005. Overview of Sauropod Phylogeny and Evolution. In: CURRY Rogers KA AND Wilson JA (Eds), The Sauropods: Evolution and Paleobiology. Berkeley: University of California, p. 15-49.

Wilson JA AND UpChURCH P. 2003. A revision of Titanosaurus Lydekker (Dinosauria-Sauropoda), the first dinosaur genus with a 'Gondwanan' distribution. J Syst Palaeontol, p. 125-160.

WITMER LM. 2002. The debate on avian ancestry, phylogeny, function, and fossils. In: CHIAPPE LM AND WITMER LM (Eds), Mesozoic birds: Above the heads of dinosaurs. Berkeley: University of California, p. 3-30.

YABUmoto Y AND Uyeno T. 2005. New materials of a Cretaceous coelacanth Mawsonia lavocati Tabaste from Morocco. Bull Nat Sci Mus C 31: 39-49.
YATES AM. 2007a. Solving a dinosaurian puzzle: the identity of Aliwalia rex Galton. Hist Biol 19: 93-123.

YATES AM. 2007b. The first complete skull of the triassic dinosaur Melanorosaurus Haughton (Sauropodomorpha: Anchisauria). In: BARRETT PM AND BATTEN DJ (Eds), Evolution and Palaeobiology of Early Sauropodomorph Dinosaurs. Spec Pap in Palaeontol 77: 57-90.

Zaher H, Pol D, Carvalho AB, Riccomini C, CAMPOS D AND NAVA W. 2006. Redescription of the cranial morphology of Mariliasuchus amarali, and its phylogenetic affinities (Crocodyliformes, Notosuchia). Am Mus Novit 3512: 1-40.

Zalán PV, WolfF S, CONCEIÇÃo JCJ, Marques A, Astolfi MAM, Vieira IS, APPI VT AND ZanotTo OA. 1990. Bacia do Paraná. In: GABAGLIA GPR AND Milani EJ (Orgs). Origem e evolução de bacias sedimentares. Rio de Janeiro, Petrobras, p. 135-165.

Zerfass H, LaVina EL, Schultz CL, Garcia AGV, FACCINI UF AND CHEMALE JR F. 2003. Sequence stratigraphy of continental Triassic strata of southernmost Brazil: a contribution to Southwestern Gondwana palaeogeography and palaeoclimate. Sediment Geol 161: 85180.

Zhou ZH, Barrett PM And Hilton J. 2003. An exceptionally preserved Lower Cretaceous ecosystem. Nature 421: 807-814. 